\title{
Initial Assessment of Bioavailable Strontium at Oldupai Gorge, Tanzania: Potential for Early Mobility Studies
}

Laura Tucker ${ }^{1}$, Julien Favreau ${ }^{1}$, Makarius Itambu ${ }^{1,2}$, Fergus Larter ${ }^{1}$, Neduvoto Mollel ${ }^{3}$, Aloyce

Mwambwiga $^{1}$, Robert Patalano ${ }^{1}$, Patrick Roberts ${ }^{4}$, María Soto ${ }^{1}$, Julio Mercader ${ }^{1,4}$

1: Department of Anthropology and Archaeology, University of Calgary, 2500 University Drive, Calgary, Alberta, Canada, T2N 1N4

2: Department of History and Archaeology, University of Dar es Salaam, P.O. Box 35091, Dar es Salaam, Tanzania

3: Tropical Pesticides Research Institute, National Herbarium of Tanzania, P.O. Box 3024, Arusha, Tanzania

4: Department of Archaeology, Max Planck Institute for the Science of Human History, Kahlaische Str. 10, 07745 Jena, Germany

\section{Corresponding author:}

Laura Tucker

lltucker@ucalgary.ca

Department of Anthropology and Archaeology, University of Calgary

2500 University Drive NW, Calgary, Alberta, T2N 1N4

\section{Declarations of interest: none}

Keywords: Oldupai Gorge, bioavailable strontium, strontium isotope analysis, diagenesis

\section{Abstract:}

Strontium isotope analysis is a useful tool for tracing mobility and migration in past populations. For it to be employed, the ${ }^{87} \mathrm{Sr} /{ }^{86} \mathrm{Sr}$ values of the landscape must be well-understood. Bioavailable strontium is a combination of geological and atmospheric strontium available for use by plants and animals. In this study we begin mapping bioavailable strontium values around the Oldupai Gorge region so that this method may be utilized on archaeological hominins and animals in the future. We analyzed three plants from 33 localities across volcanic and metamorphic bedrock, including the regional drainage sump, Olbalbal. We found that bioavailable strontium in the region is homogeneous overall, with trends towards increasing values to the north and northeast 
35 and in Olbalbal. There was no difference between ${ }^{87} \mathrm{Sr} /{ }^{86} \mathrm{Sr}$ values of metamorphic and volcanic 36 areas. Migrants from outside the study area with different isotopic values will be easily identifiable 37 from the local residents.

38 As a proof of concept, we analyzed 7 animal teeth (hippopotamus, crocodile, and equid) from 39 Engaji Nanyori, a Bed III and IV site at Oldupai Gorge. We found that enamel and dentine which 40 had been acetic acid treated to remove diagenetic strontium were significantly different from one 41 another. All animals had higher ${ }^{87} \mathrm{Sr} /{ }^{86} \mathrm{Sr}$ values than the plant values, suggesting that modern and 42 ancient bioavailable strontium values may have been different, likely due to environmental 43 differences. 


\section{Introduction}

The largest contributor of strontium ions and leading cause of landscape ${ }^{87} \mathrm{Sr} /{ }^{86} \mathrm{Sr}$ variation is bedrock (Faure and Powell, 1972; Faure, 1986, Sealy et al., 1991, Bentley, 2006), though atmospheric and hydrological sources also contribute strontium (Franzén, 1980; Gosz et al., 1983; Graustein and Armstrong, 1983; Wadleigh et al., 1985; Palmer and Edmond, 1989; Andersson et al., 1990; Clow et al., 1997; Böhlke and Horan, 2000; Hosono et al., 2007; Evans et al., 2010). Bioavailable strontium is labile to plants and animals (Sillen et al., 1998; Beard and Johnson, 2000), being incorporated into their tissues after they eat and drink (Bentley, 2006). Strontium isotopes do not fractionate in biological systems, so ${ }^{87} \mathrm{Sr} /{ }^{86} \mathrm{Sr}$ values of skeletal materials directly reflect what is consumed (Capo et al., 1998; Bentley, 2006).

Strontium isotopes from skeletons provide insights into landscape use and mobility (Bentley 2006). This method has been extensively utilized for anatomically modern humans (Ericson, 1985; Knudson et al., 2005; Conlee et al., 2009; Nystrom et al., 2011; Slovak et al., 2009; Frei and Price, 2012; Wright, 2012; Perry et al., 2017), but only rarely for archaic hominins from southern Africa (Sillen et al., 1995; 1998; Copeland et al., 2011). Landscape bioavailable strontium values can be determined by analyzing waters (Frei and Frei, 2011), plants (Hartman and Richards, 2014; Copeland et al., 2016), domesticated animals (Bentley et al., 2004) rodents (Kootker et al., 2016), and land snails (Evans et al., 2009, 2010; Maurer et al., 2012). Isoscapes then allow for interpreting skeletal strontium data (e.g. Copeland et al., 2016; Evans et al., 2010; Hartman and Richards, 2014; Kootker et al., 2016).

Here, we implement a sampling strategy to build an initial map of bioavailable strontium for the Oldupai Gorge region: a site complex yielding an extraordinary record of hominin evolution (Hay, 1976; Leakey, 1971). We studied plants from 33 locations across $\sim 750 \mathrm{~km}^{2}$ to outline 
$67{ }^{87} \mathrm{Sr} /{ }^{86} \mathrm{Sr}$ variation. The outcome underscores the potential of strontium analysis in East Africa. We

68 argue that this method can track hominin land-use, social connectivity, and mobility; noting

69 methodological caveats surrounding variability in bioavailable strontium unrelated to bedrock

70 levels. We present ${ }^{87} \mathrm{Sr} /{ }^{86} \mathrm{Sr}$ data from enamel and dentine from Engaji Nanyori (Oldupai Gorge

71 Bed III) as a proof of concept.

72

73 2. Background

$74 \quad 2.1$ Using Strontium Values at the Landscape Level

75 "Locals" and “non-locals" are identified by comparing archaeological values to

76 bioavailable strontium in the region. ${ }^{87} \mathrm{Sr}$ forms from the $\beta$ - decay of ${ }^{87} \mathrm{Rb}$, gradually increasing

77 over time, whereas ${ }^{86} \mathrm{Sr}$ remains constant (Faure and Powell, 1972; Bentley, 2006). Older,

78 rubidium-rich rocks containing little ${ }^{86} \mathrm{Sr}$ have the highest ${ }^{87} \mathrm{Sr} /{ }^{86} \mathrm{Sr}$ values. Plants are reliable

79 proxies of bioavailable strontium (Evans et al., 2009; Maurer et al., 2012; Copeland et al., 2016),

80 and can be used to create isoscapes, though they may have variable ${ }^{87} \mathrm{Sr} /{ }^{86} \mathrm{Sr}$ due to differences in

81 root depth and nutrient cycling (Poszwa et al., 2004; Maurer et al., 2012; Hartman and Richards,

82 2014; Flockhart et al., 2015).

83

Dental ${ }^{87} \mathrm{Sr} /{ }^{86} \mathrm{Sr}$ values indicate residence during tooth formation, whereas bone values

84 indicate location later in life. Inter- and intra-tooth sampling are useful for tracing mobility over

85 time (Britton et al., 2009, 2011; Copeland et al., 2016; cf. Balasse, 2003). Diagenesis of skeletal

86 material is problematic, as biogenic strontium is replaced with geological values (Sillen, 1986;

87 Bentley et al., 2004). Enamel is most resilient, followed by dentine and bone (Budd et al., 2000;

88 Lee-Thorp and Sponheimer, 2003). The effect of diagenesis can be muted by a weak acid (Sillen 
89 and Sealy, 1995; Lee-Thorp and Sponheimer, 2003; cf. Sillen, 1986), though it causes fossilized 90 enamel to break down (Lee-Thorp et al., 1997).

$92 \quad 2.2$ Study Area

Oldupai Gorge is in Tanzania’s Ngorongoro Conservation Area (NCA) (2 59' 46.87” S, $9435^{\circ} 21^{\prime} 7.50^{\prime \prime}$ E) along the Volcanic Highlands (NVH). North of the Gorge are metamorphic massifs, and to the east is the Olbalbal depression (Figure 2.1) (Hay, 1976). Local ecosystems are diverse and include forest, heath, and the Acacia Commiphora woodlands of the Serengeti from 1,350 to 1,850 m asl (Herlocker and Dirschl, 1972). December through April are the wettest months, and June through October are driest (Pearsall, 1957; Anderson and Talbot, 1965; Norton99 Griffiths et al., 1975). Annual precipitation is 331-531 mm (Herlocker and Dirschl, 1972; NortonGriffiths et al., 1975; Hay, 1976). Soils are shallow. Conductivity, pH, and sodium are high, and 101 their average temperature $22{ }^{\circ} \mathrm{C}$ (Jager, 1982). Above ground temperature fluctuates from $12{ }^{\circ} \mathrm{C}$ to $33^{\circ} \mathrm{C}$. Evaporation reaches $10 \mathrm{~mm} /$ day (Hay, 1976). Wind is easterly $(12.4 \mathrm{~km} / \mathrm{h})$. The Eastern 103 Serengeti Plains drain into the main branch of Oldupai Gorge via the Oldupai River, from Lakes 104 Masek and Ndutu and terminating in the Olbalbal depression (Leakey, 1978; Scoon, 2018). The 105 Side Gorge stream originates on Lemagrut, a volcano to the south (Leakey, 1978).

\subsection{Geology and Palaeoanthropology}

Oldupai Gorge is on the western flank of the Gregory Rift (Dawson, 1992; Ashley and 109 Hay, 2002; Chorowicz, 2005). It is underlain by the metamorphic rocks from the Mozambique Belt and covered by Plio-Pleistocene materials (Anderson and Talbot, 1965; Hay, 1976; Nyamai 111 et al., 2001; Mollel and Swisher, 2012). The Archean Tanzania Craton borders the Mozambique 


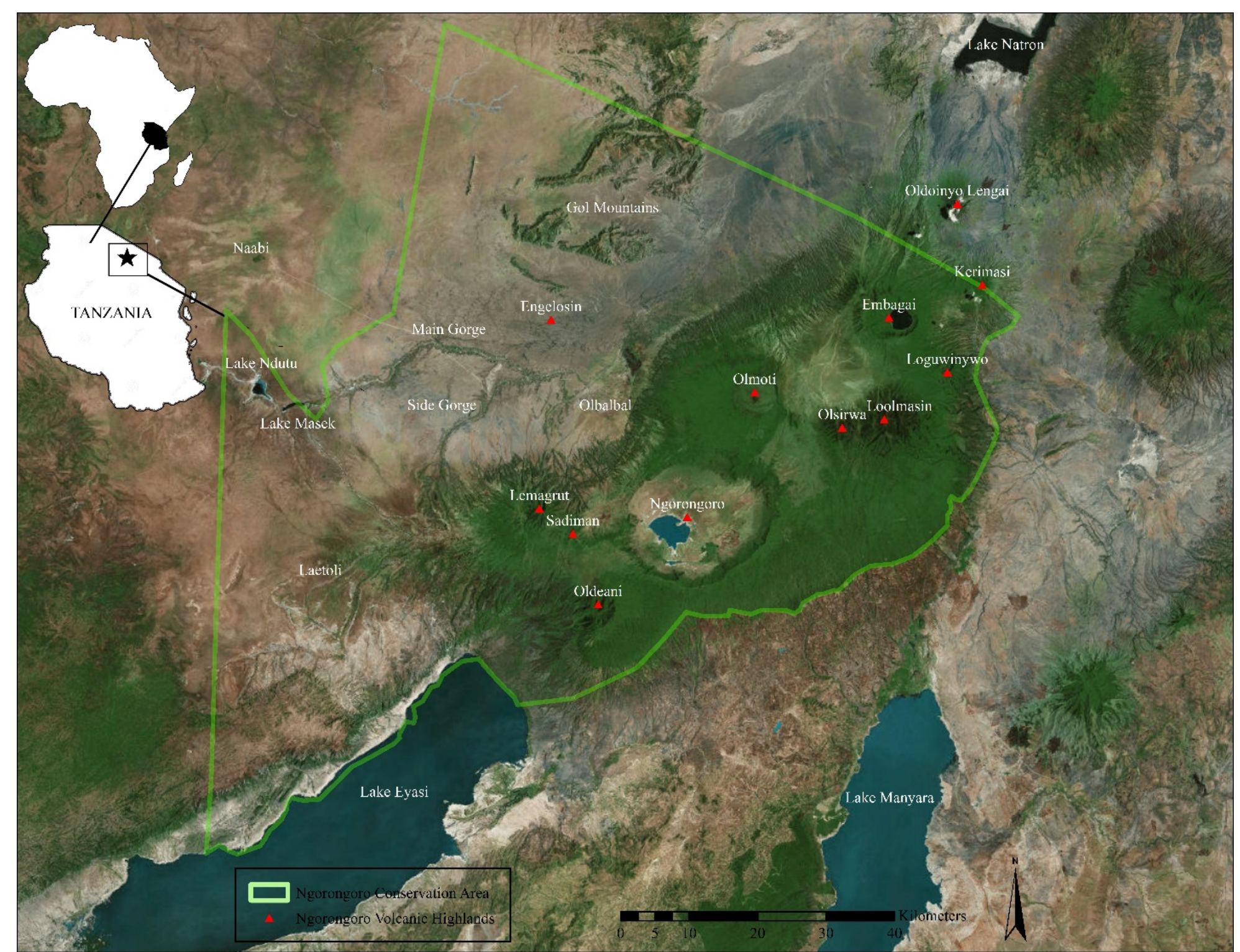

112

Figure 2.1: Maps showing the location of the NCA and various landmarks within it. Basemap Source: Esri, DigitalGlobe, GeoEye, 
115 Belt to the west, approximately $25 \mathrm{~km}$ west of Lakes Ndutu and Masek (Hay, 1976). These rocks

116 have been stable for $2.5 \mathrm{Ga}$, and primarily consist of granitoides and greenstones (Hay, 1976;

117 Manya et al., 2007).

118 The basal unit at Oldupai Gorge is the Naabi ignimbrite: pyroclastic rock from Ngorongoro 119 volcano dated to $2.038 \pm 0.005$ Ma (McHenry et al., 2008; Deino, 2012; cf. Habermann et al., 120 2016). It is covered unconfomably by the Oldupai Group, which has a maximum thickness of about $121100 \mathrm{~m}$ and includes seven distinct sedimentary units: Bed I-IV, Masek, Ndutu, and Naisiusiu (Hay, 122 1976). The most recent deposits are from Oldoinyo Lengai (Hay, 1976). Oldupai Gorge has been 123 incised for the last $\sim 400$ ka by the river (Hay, 1976).

Oldupai Gorge is famous for containing a 2-million-year record of hominin evolution (e.g.

125 Kleindienst, 1973; Day and Molleson, 1976; Hay, 1976; Domínguez-Rodrigo et al., 1997; 2015; 126 2017; Fernández-Jalvo et al., 1999; McHenry et al., 2007; Blumenschine et al., 2012; de la Torre 127 et al., 2012; Pante, 2013; Diez-Martin, et al. 2015; Hlusko et al., 2015; Organista et al., 2016). 128 Beds I and II yield the densest archaeological assemblages and are studied the most (Hay, 1976). 129 Bed I includes the largest Early Pleistocene archaeological sites, David’s Site (Domínguez130 Rodrigo et al., 2017) and FLK Zinj (Leakey, 1971). Paranthropus boisei (Domínguez-Rodrigo et 131 al., 2013), Homo habilis (Leakey et al., 1964; Johanson et al., 1987), and Homo erectus (Rightmire, 132 1979) have been found there.

\subsection{Plant and Animal Ecology}

The NCA is in the Somalia-Masai floristic zone. Acacia-Commiphora bush and thicket is 136 the climax vegetation and woodlands and grasslands are present, though low woodland is the most 137 common physiognomy (Herlocker and Dirschl, 1972; Kindt et al., 2011). Grasslands can be 
138 classified as long (dominated by Themeda triandra), intermediate (dominated by Andropogon 139 greenwayii), and short (dominated by Digitaria macroblephara and Microchloa kunthii), which 140 are most common (Anderson and Talbot, 1965; Herlocker and Dirschl, 1972; Norton-Griffiths et 141 al., 1975).

Oldupai Gorge can be broken into three physiographic units: the west, the east, and the south fork tributary (Herlocker and Dirschl, 1972). The west is shallow and homogeneous in flora, 144 featuring a low woodland of predominantly Commiphora kua, Acacia mellifera, and Acacia 145 tortilis, a bushy layer comprised mainly of Sansevieria robusta, Cissus quadrangularis, and Cissus 146 cactiformis, and the grasses Sporobolus consimilis, Sporobolus ioclades, Pennisetum mezianum, 147 Chloris gayana, and Digitaria macroblephara. The east has steeper canyon walls, more open tree 148 coverage, and contains many species found in the west. Additional species include Salvadora 149 persica, Lycium spp., and Justicia betonica. The southern fork tributary includes the same species, 150 plus the trees Acacia drepanolobium and Acacia gerrardi, and the grasses Enneapogon persica, 151 Themeda triandra, and Aristida adscensionis (Herlocker and Dirschl, 1972). There are 32 152 published genera of plants near Oldupai Gorge (Herlocker and Dirschl, 1972).

Animal ecology must be considered when interpreting their ${ }^{87} \mathrm{Sr} /{ }^{86} \mathrm{Sr}$ values, as diet and 154 ranging behaviour will impact their ${ }^{87} \mathrm{Sr} /{ }^{86} \mathrm{Sr}$ values. During the wet season there are many grazers 155 throughout the NCA, such as Thompson's gazelles (Gazella tomsonii), zebra (Equus burchelli), 156 and wildebeest (Connochaetes taurinus). They typically migrate to the northwest portion of the 157 Serengeti in the dry season (Anderson and Talbot, 1965; Sinclair et al., 2007). Giraffes (Giraffe 158 camelopardalis), various browsing antelopes, African buffalo (Syncerus caffer), and elephants 159 (Loxodonta africana) are also present, of which giraffes and some browsing antelopes remain year160 round. Predators include lions (Panthera leo), leopards (Panthera pardus), hyaenas (Hyena 
161 hyaena, Crocuta crocuta) jackals (Canis spp.), and cheetahs (Acinonyx jubatus) (Kennedy and

162 Kennedy, 2014). Reptiles include snakes like the black-necked spitting cobra (Naja nigricollis)

163 and the black mamba (Dendroaspis polylepis), agama lizards (Agama spp.), and leopard tortoises

164 (Geochelone pardalis) (Kennedy and Kennedy, 2014). Large-bodied birds include ostriches

165 (Struthio camelus), secretary birds (Sagittarius serpentarius), and kori bustards (Ardeotis kori),

166 and small-bodied birds include Kittlitz’s plover (Charadrius pecuarius), southern ground hornbill

167 (Bucorvus leadbeateri), and white-backed vultures (Gyps africanus) (Kennedy, 2014).

168

169

\subsection{Palaeoenvironment and Palaeoclimate}

170

During Bed I and Bed II times there was a large palaeo-lake at Oldupai (Hay, 1976). Bed

171 I lake deposits are primarily comprised of claystone and contain authigenic minerals suggesting

172 very saline, alkaline water (Hay, 1976). Paleosol carbonate $\delta^{13} \mathrm{C}$ values from non-lacustrine areas

173 imply that $\mathrm{C}_{4}$ vegetation was expanding and temperature was increasing over the past two million

174 years (Cerling and Hay, 1986). Variable Bed $\mathrm{I} \delta^{18} \mathrm{O}$ values suggest fluctuating amounts of

175 precipitation (Sikes and Ashley, 2007).

176

Silicified plant parts, phytoliths, and pollen grains have been used for palaeoenvironmental

177 reconstruction at Oldupai (Bamford, 2005, 2012; Bamford et al., 2006; 2008; Barboni et al., 2010;

178 Albert et al., 2015). This work has focused on Beds I and II. Remains of sedges and Typha confirm

179 the presence of a permanent water source in the area (Bamford, 2012). Grasses were identified

180 (Bamford, 2012), as has Guibourtia coleosperma, which is not present today (Bamford, 2005).

181 Phytoliths from FLK N and FLK Zinj suggest that vegetation was spatially heterogeneous, with

182 wooded areas and grasslands (Bamford, 2005, 2012). Freshwater springs had denser vegetation,

183 including palms and sedges (Barboni et al., 2010). 
185

\subsection{Engaji Nanyori}

Engagi Nanyori (EN; also known as Juma’s Korongo) is an archaeological site spanning Beds III and IV at Oldupai Gorge (1.15 to $0.8 \mathrm{Ma}$ ) (Hay, 1976; Manega, 1993; McHenry et al., 2007; Pante, 2013). This site formed mainly by fluvial and deltaic deposition (Hay, 1976). Faunal remains include hominids, cercopithecids, lagomorphs, rodents, carnivores, Proboscidea, Perissodactyla, Artiodactyla, crocodiles, and fish (Kleindienst, 1973; Day and Molleson, 1976). Preservation of fossils and lithics varies from extremely weathered to well-preserved (Kleindienst, 1973).

The eastern portion of the site has Beds III and IV deposits that are approximately $20 \mathrm{~m}$ thick, and the west side has $11 \mathrm{~m}$ thick deposits and represent only Bed III (Kleindienst, 1973). Leakey and Roe (1994) describe four stratigraphic layers: coarse grey sands containing artifacts, fine red sands, pink siltstone, and artifact-containing clay. Geological evidence suggests that deposits at EN were formed via back channels or stream channels moving north (Kleindienst, 1973; Leakey and Roe, 1994). These streams may have created perennial pools or supplied a marshland with water (Kleindienst, 1973).

\section{Materials and Methods}

\subsection{Plant Sampling}

Plants were collected from 33 localities over $750 \mathrm{~km}^{2}$ (Figure 3.1; Table 3.1). Localities were selected on both volcanic and metamorphic bedrock to look for geological-based variation in ${ }^{87} \mathrm{Sr} /{ }^{86} \mathrm{Sr}$ values. Sampling localities were primarily north of Oldupai to capture geological variability not seen to the south. Samples were collected $\sim 3-5 \mathrm{~km}$ apart to identify variability in 


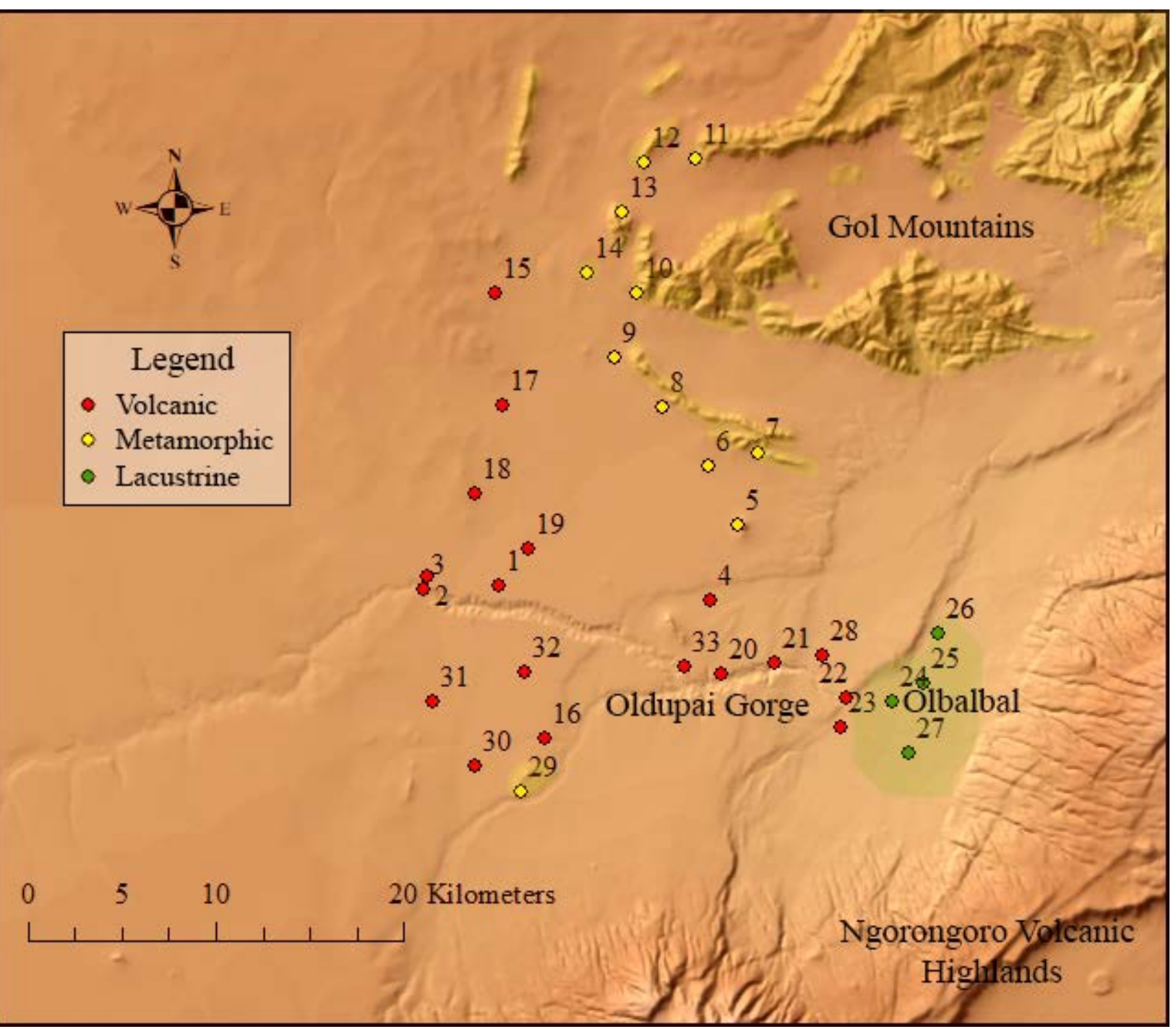

Figure 3.1: Locations of sampling localities, their geological domains, and the lacustrine area sampled. Basemap source: Airbus, USGS, NGA, NASA, CGIAR, NLS, OS, NMA, Geodatastyrelsen, GSA, GSI and the GIS User Community.

212 bioavailable strontium within the geological domains. Five samples were taken from the

213 Olbalbal depression to examine hydrological effects on strontium values. Geographical data were

214 recorded with a Garmin eTrex 10 Global Positioning System (GPS) unit. Three plants were

215 collected from each locality (Table 3.2). When possible, multiple types of plants and parts were

216 collected to account for variation in ${ }^{87} \mathrm{Sr} /{ }^{86} \mathrm{Sr}$ values. Only plants that could be identified to the

217 genus level were collected. Plants were stored in envelopes and air dried prior to identification at 


\begin{tabular}{|c|c|c|c|c|}
\hline Locality & Geology & Longitude & Latitude & Elevation \\
\hline 1 & Volcanic & 35.264876 & -2.943339 & 1538.225 \\
\hline 2 & Volcanic & 35.230379 & -2.938182 & 1557.068 \\
\hline 3 & Volcanic & 35.228828 & -2.944456 & 1532.922 \\
\hline 4 & Volcanic & 35.365573 & -2.950064 & 1458.82 \\
\hline 5 & Volcanic & 35.378778 & -2.914144 & 1559.691 \\
\hline 6 & Volcanic & 35.364292 & -2.886326 & 1544.882 \\
\hline 7 & Metamorphic & 35.3884 & -2.880129 & 1586.366 \\
\hline 8 & Metamorphic & 35.342504 & -2.858052 & 1592.784 \\
\hline 9 & Metamorphic & 35.320004 & -2.834773 & 1589.259 \\
\hline 10 & Metamorphic & 35.330545 & -2.803343 & 1682.532 \\
\hline 11 & Metamorphic & 35.358697 & -2.740078 & 1810.15 \\
\hline 12 & Metamorphic & 35.333732 & -2.741435 & 1753.209 \\
\hline 13 & Metamorphic & 35.323153 & -2.764971 & 1760.194 \\
\hline 14 & Metamorphic & 35.306921 & -2.793945 & 1650.591 \\
\hline 15 & Volcanic & 35.263021 & -2.804032 & 1669.861 \\
\hline 16 & Volcanic & 35.286581 & -3.015409 & 1513.919 \\
\hline 17 & Volcanic & 35.266424 & -2.857492 & 1587.489 \\
\hline 18 & Volcanic & 35.253132 & -2.899225 & 1602.297 \\
\hline 19 & Volcanic & 35.278495 & -2.925186 & 1531.983 \\
\hline 20 & Volcanic & 35.37066 & -2.985356 & 1450.513 \\
\hline 21 & Volcanic & 35.396601 & -2.980115 & 1423.267 \\
\hline 22 & Volcanic & 35.42993 & -2.995884 & 1362.494 \\
\hline 23 & Lacustrine & 35.427352 & -3.01027 & 1313.31 \\
\hline 24 & Lacustrine & 35.451995 & -2.9978 & 1302.591 \\
\hline 25 & Lacustrine & 35.467404 & -2.989666 & 1291.68 \\
\hline 26 & Lacustrine & 35.474165 & -2.96554 & 1285.367 \\
\hline 27 & Lacustrine & 35.459827 & -3.022632 & 1292.851 \\
\hline 28 & Volcanic & 35.419005 & -2.976165 & 1358.419 \\
\hline 29 & Metamorphic & 35.275396 & -3.04128 & 1537.336 \\
\hline 30 & Volcanic & 35.253204 & -3.028353 & 1538.32 \\
\hline 31 & Volcanic & 35.232917 & -2.998455 & 1557.236 \\
\hline 32 & Volcanic & 35.276675 & -2.984336 & 1521.02 \\
\hline 33 & Volcanic & 35.353044 & -2.981804 & 1458.466 \\
\hline
\end{tabular}

218 Table 3.1: Geographical and geological information for each sampling locality.

219

220 the Tropical Pesticides Research Institute in Arusha, Tanzania, and exported to the University of

221 Calgary, Canada for strontium isotope analysis. 


\begin{tabular}{|c|c|c|c|c|}
\hline Sample & Locality & Family & Genus & Parts Collected \\
\hline 1 & 1 & Acanthaceae & Hypoestes forskaolii & stems, flowers, roots \\
\hline 2 & 1 & Fabaceae & Acacia tortilis & branches, leaves, thorns \\
\hline 3 & 1 & Fabaceae & Acacia tortilis & branches, leaves, thorns \\
\hline 4 & 2 & Balanitaceae & Balanites aegyptiaca & branches, leaves, thorns, bark \\
\hline 5 & 2 & Burseraceae & Commiphora sp. & branches, leaves \\
\hline 6 & 2 & Fabaceae & Acacia tortilis & branches, leaves, thorns \\
\hline 7 & 3 & Poaceae & Sporobolus consimilis & blades, flowers \\
\hline 8 & 3 & Poaceae & Pennisetum mezianum & blades, flowers \\
\hline 9 & 3 & Capparaceae & Boscia angustifolia & branches, leaves \\
\hline 10 & 4 & Asparagaceae & Asparagus africanus & branches, leaves \\
\hline 11 & 4 & Fabaceae & Acacia mellifera & branches, leaves \\
\hline 12 & 4 & Amaranthaceae & Achyranthes aspera & branches, leaves, seeds \\
\hline 13 & 5 & Amaranthaceae & Achyranthes aspera & branches, leaves \\
\hline 14 & 5 & Asparagaceae & Asparagus africanus & branches, leaves \\
\hline 15 & 5 & Poaceae & Aristidia adoensis & blades, flowers \\
\hline 16 & 6 & Acanthaceae & Barleria stuhlmannii & stems, leaves, flowers \\
\hline 17 & 6 & Amaranthaceae & Achyranthes aspera & branches, leaves, seeds \\
\hline 18 & 6 & Olacaceae & Ximenia caffra & branches, leaves \\
\hline 19 & 7 & Euphorbiaceae & Euphorbia cuneata & branches, leaves, fruit \\
\hline 20 & 7 & Asparagaceae & Asparagus africanus & stems, leaves \\
\hline 21 & 7 & Poaceae & Enneapogon cenchroides & blades, flowers \\
\hline 22 & 8 & Fabaceae & Acacia tortilis & branches, leaves, thorns \\
\hline 23 & 8 & Acanthaceae & Hypoestes forskaolii & stems, leaves, flowers \\
\hline 24 & 8 & Boraginaceae & Heliotropium steudneri & stems, leaves, flowers \\
\hline 25 & 9 & Acanthaceae & Hypoestes forskaolii & stems, leaves, flowers \\
\hline 26 & 9 & Poaceae & Sporobolus panicoides & blades, flowers \\
\hline 27 & 9 & Acanthaceae & Hypoestes forskaolii & stems, leaves, flowers \\
\hline 28 & 10 & Boraginaceae & Cordia monoica & branches, leaves \\
\hline 29 & 10 & Fabaceae & Acacia xanthophloea & branches, thorns, leaves \\
\hline 30 & 10 & Asteraceae & Conyza pyrrhopappa & branches, leaves \\
\hline 31 & 11 & Boraginaceae & Cordia monoica & branches, leaves \\
\hline 32 & 11 & Amaranthaceae & Achyranthes aspera & branches, leaves \\
\hline 33 & 11 & Malvaceae & Hibiscus ludwigii & branches, leaves, flower, buds \\
\hline 34 & 12 & Fabaceae & Acacia drepanolobium & branches, leaves, thorns, fruit \\
\hline 35 & 12 & Burseraceae & Commiphora kua & leaves, branches \\
\hline 36 & 12 & Asparagaceae & Asparagus africanus & stems, leaves \\
\hline 37 & 13 & Burseraceae & Commiphora merkeri & branches, leaves \\
\hline 38 & 13 & Boraginaceae & Cordia monoica & branches, leaves \\
\hline 39 & 13 & Asteraceae & Conyza pyrrhopappa & branches, leaves \\
\hline 40 & 14 & Solanaceae & Withania somnifera & branches, leaves \\
\hline 41 & 14 & Fabaceae & Acacia tortilis & branches, leaves, thorns \\
\hline 42 & 14 & Acanthaceae & Hypoestes forskaolii & stems, leaves, flowers \\
\hline 43 & 15 & Amaranthaceae & Achyranthes aspera & branches, leaves \\
\hline
\end{tabular}




\begin{tabular}{|c|c|c|c|c|}
\hline 44 & 15 & Boraginaceae & Heliotropium steudneri & branches, leaves \\
\hline 45 & 15 & Asparagaceae & Asparagus africanus & stems, leaves \\
\hline 46 & 16 & Burseraceae & Commiphora sp. & branches, leaves \\
\hline 47 & 16 & Fabaceae & Acacia tortilis & branches, leaves, thorns \\
\hline 48 & 16 & Poaceae & Sporobolus panicoides & blades, flowers, roots \\
\hline 49 & 17 & Poaceae & Sporobolus panicoides & blades, flowers, roots \\
\hline 50 & 17 & Poaceae & Digitaria macroblephara & blades, flowers, roots \\
\hline 51 & 17 & Poaceae & Digitaria macroblephara & blades, flowers, roots \\
\hline 52 & 18 & Olacaceae & Ximenia caffra & branches, leaves \\
\hline 53 & 18 & Boraginaceae & Heliotropium steudneri & branches, leaves \\
\hline 54 & 18 & Fabaceae & Acacia mellifera & branches, leaves \\
\hline 55 & 19 & Acanthaceae & Barleria eranthemoides & stems, leaves, flowers \\
\hline 56 & 19 & Acanthaceae & Justicia betonica & stems, leaves \\
\hline 57 & 19 & Poaceae & Sporobolus panicoides & blades, flowers \\
\hline 58 & 20 & Olacaceae & Ximenia caffra & branches, leaves \\
\hline 59 & 20 & Burseraceae & Commiphora merkeri & branches, leaves \\
\hline 60 & 20 & Fabaceae & Acacia mellifera & branches, leaves \\
\hline 61 & 21 & Vitaceae & Cissus quadrangularis & branches \\
\hline 62 & 21 & Asphodelaceae & Aloe secundiflora & leaves \\
\hline 63 & 21 & Asparagaceae & Asparagus africanus & branches, leaves \\
\hline 64 & 22 & Balanitaceae & Balanites aegyptiaca & branches, leaves, thorns \\
\hline 65 & 22 & Fabaceae & Acacia mellifera & branches, leaves \\
\hline 66 & 22 & Olacaceae & Ximenia caffra & branches, leaves \\
\hline 67 & 23 & Balanitaceae & Balanites aegyptiaca & branches, leaves \\
\hline 68 & 23 & Fabaceae & Acacia tortilis & branches, leaves, thorns \\
\hline 69 & 23 & Poaceae & Sporobolus panicoides & blades, flowers \\
\hline 70 & 24 & Balanitaceae & Balanites aegyptiaca & branches, leaves \\
\hline 71 & 24 & Balanitaceae & Balanites aegyptiaca & branches, leaves \\
\hline 72 & 24 & Fabaceae & Acacia tortilis & branches, leaves \\
\hline 73 & 25 & Fabaceae & Acacia mellifera & branches, leaves \\
\hline 74 & 25 & Fabaceae & Acacia tortilis & branches, leaves, thorns \\
\hline 75 & 25 & Poaceae & Pennisetum mezianum & blades, flowers, roots \\
\hline 76 & 26 & Amaranthaceae & Achyranthes aspera & branches, leaves \\
\hline 77 & 26 & Fabaceae & Acacia xanthophloea & branches, leaves \\
\hline 78 & 26 & Balanitaceae & Balanites aegyptiaca & branches, leaves \\
\hline 79 & 27 & Capparaceae & Cadaba farinosa & branches, leaves \\
\hline 80 & 27 & Fabaceae & Acacia tortilis & branches, leaves \\
\hline 81 & 27 & Solanaceae & Lycium europaeum & branches, leaves \\
\hline 82 & 28 & Amaranthaceae & Achyranthes aspera & branches, leaves \\
\hline 83 & 28 & Burseraceae & Commiphora sp. & branches, leaves \\
\hline 84 & 28 & Balanitaceae & Balanites aegyptiaca & branches, leaves \\
\hline 85 & 29 & Salvadoraceae & Salvadora persica & branches, leaves \\
\hline 86 & 29 & Asparagaceae & Asparagus africanus & stems, leaves \\
\hline 87 & 29 & Poaceae & Aristidia adoensis & blades, roots, flowers \\
\hline
\end{tabular}




\begin{tabular}{|c|c|c|c|c|}
\hline 88 & 30 & Asparagaceae & Asparagus africanus & branches, leaves \\
\hline 89 & 30 & Fabaceae & Acacia tortilis & branches, leaves, thorns \\
\hline 90 & 30 & Asparagaceae & Asparagus africanus & branches, leaves, fruit \\
\hline 91 & 31 & Asparagaceae & Asparagus africanus & branches, leaves \\
\hline 92 & 31 & Fabaceae & Acacia tortilis & branches, leaves, thorns \\
\hline 93 & 31 & Fabaceae & Senna italica & leaves, flowers, stems, fruits \\
\hline 94 & 32 & Poaceae & Digitaria macroblephara & blades, flowers, roots \\
\hline 95 & 32 & Poaceae & Sporobolus panicoides & blades, flowers, roots \\
\hline 96 & 32 & Convulvulaceae & Ipomoea sp. & branches, leaves \\
\hline 97 & 33 & Boraginaceae & Cordia monoica & branches, leaves \\
\hline 98 & 33 & Poaceae & Cynodon dactylon & blades, roots \\
\hline 99 & 33 & Acanthaceae & Barleria eranthemoides & branches, leaves \\
\hline
\end{tabular}

223

224

225

226

227

228

229

230

231

232

233

234

235

236

237

238

239

240

Table 3.2: Species and parts of plants sampled from each locality

\subsection{Excavation}

All teeth were excavated by the Stone Tools, Diet, and Sociality (SDS) team at EN in July 2017 (Figure 3.2). Teeth were found in or near six geotrenches. These include isolated teeth from equids ( $n=2)$, crocodiles $(n=3)$, and a hippopotamus $(n=1)$ (Table 3.3). The outer surface of EN6 was cracked all over and flaking. The remaining teeth were in better condition. EN7 was encased in rock with the crown exposed. The teeth were exported to the University of Calgary.

\subsection{Plant Laboratory Methods}

In the SDS Preparations Laboratory at the University of Calgary, $\sim 1 \mathrm{~g}$ of each plant was cut into small pieces. The three plants from each locality were combined in sample bags. Cutting implements were cleaned with 99\% isopropyl alcohol to avoid cross-contamination. The plants were ashed in sterile, covered crucibles at $400{ }^{\circ} \mathrm{C}$ for 48 hours in the Tropical Archaeology Laboratory (TAL) at the University of Calgary. In the Isotope Science Laboratory (ISL) at the University of Calgary, 10-15 mg of ash was placed in $1.5 \mathrm{~mL}$ centrifuge tubes, digested in $500 \mu \mathrm{L}$ of $3 \mathrm{M} \mathrm{HNO}_{3}$ for two hours, and centrifuged at 3000 rpm for 3 minutes. 


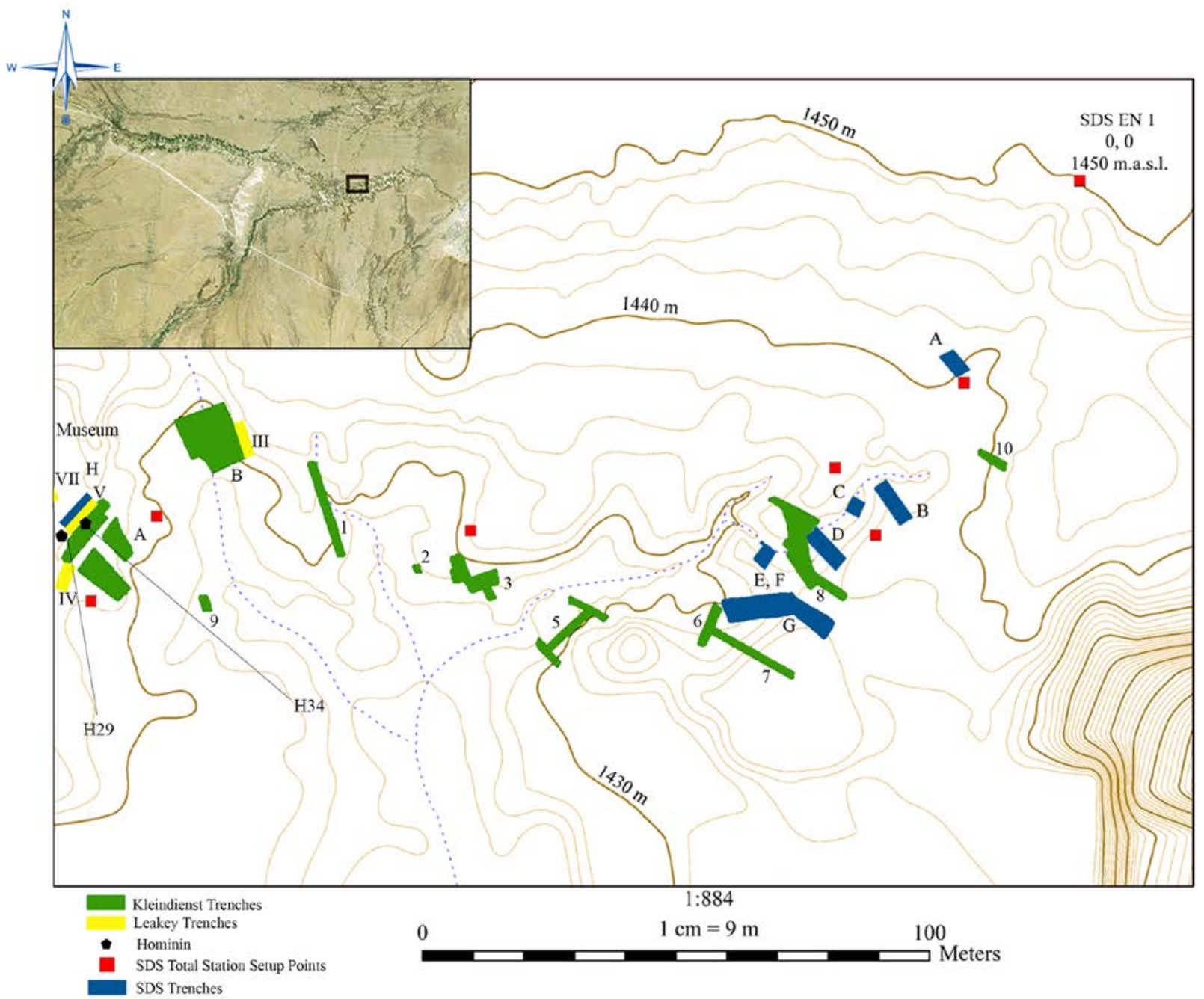

242 Figure 3.2: Topographical map of Engaji Nanyori and the locations of trenches excavated.

\begin{tabular}{|l|l|l|l|}
\hline Specimen & Taxon & Tooth Type & Provenance \\
\hline EN1 & Equid & Molar & South of E \\
EN2 & Crocodile & Unknown & B \\
EN3 & Crocodile & Unknown & D \\
EN4 & Crocodile & Unknown & F \\
EN5 & Crocodile & Unknown & B \\
EN6 & Equid & Molar & D \\
EN7 & Hippopotamus & Molar & D \\
\hline
\end{tabular}


247

248

249

250

251

252

253

254

255

256

257

258

259

260

261

262

263

264

265

266

267

268

\subsection{Tooth Preparation}

In the Preparation Laboratory, the teeth were brushed to remove surface sediment, then grazed with a Dremel Engraver tool with a $1.2 \mathrm{~mm}$ diamond-tipped bit on medium speed to remove remaining contaminants. The Dremel was used to remove 10 mg each of enamel and dentine. The bit was cleaned with 99\% isopropyl between samples and teeth. When sampling EN7 low speed was used to keep the concretion intact.

In the TAL the samples were subdivided into two 3-5 mg subsamples. One set of enamel and dentine from each tooth was soaked in $500 \mu \mathrm{L}$ of $0.1 \mathrm{M}$ acetic acid for 30 minutes to remove diagenetic strontium. The other half were left untreated to see if diagenetic strontium was removed. The tubes were filled with RODI water, centrifuged at $5000 \mathrm{rpm}$ for 5 minutes, and the supernatant removed. The samples were rinsed to neutrality and dried overnight under a heat lamp. Next, samples were transferred into sterile Teflon jars, dissolved in $500 \mu \mathrm{L}$ of $5 \mathrm{M} \mathrm{HNO}_{3}$ and $50 \mu \mathrm{L}$ of $\mathrm{H}_{2} \mathrm{O}_{2}$, and heated overnight on a hotplate at $60{ }^{\circ} \mathrm{C}$. To leach strontium, $500 \mu \mathrm{L}$ of $3 \mathrm{M} \mathrm{HNO}_{3}$ was added and allowed to react for two hours.

\subsection{Isotope Analyses}

All samples were analyzed in the ISL. $100 \mu \mathrm{L}$ of Eichrom Sr Resin $(50-100 \mu \mathrm{m})$ was put into glass ion exchange columns, pre-cleaned with $3 \mathrm{~mL}$ of Milli-Q $\mathrm{H}_{2} \mathrm{O}$, and pre-conditioned with $500 \mu \mathrm{L}$ of $3 \mathrm{M} \mathrm{HNO}_{3}$. The supernatants from the plants and all of the dental samples were placed into the columns and dissolved in $500 \mu \mathrm{L}$ of $3 \mathrm{M} \mathrm{HNO}_{3}$. The resin was rinsed twice with $1 \mathrm{~mL}$ of $3 \mathrm{M} \mathrm{HNO}_{3}$, then the strontium was eluted with $500 \mu \mathrm{L}$ of Milli-Q $\mathrm{H}_{2} \mathrm{O}$ and collected in $1.5 \mathrm{~mL}$ centrifuge tubes. Samples were dried under a heat lamp for 48 hours. 
The samples were analysed on a Thermo-Fisher Triton thermal ionization mass

270

271

272

273

274

275

276

277

278

279

280

281

282 spectrometer (TIMS). Each carousel was run with the international standard NIST SRM 987 to ensure external precision, yielding an analytical reproducibility of \pm 0.000013 . Two duplicate samples were prepared for each carousel. ${ }^{87} \mathrm{Sr} /{ }^{86} \mathrm{Sr}$ ratios were calculated 150 times, and measurements within two standard deviations of the mean were used to calculate the final values.

${ }^{85} \mathrm{Rb}$ was monitored to correct for interference from ${ }^{87} \mathrm{Rb}$. All ${ }^{87} \mathrm{Sr} /{ }^{86} \mathrm{Sr}$ ratios were normalised against instrumental mass bias using the ratio ${ }^{88} \mathrm{Sr} /{ }^{86} \mathrm{Sr}=8.375209$.

\subsection{Data Analyses}

Google Earth Pro, ArcGIS Desktop 10.6, and Adobe Photoshop Creative Cloud 2015 generated our maps and figures. Microsoft Excel 2016 facilitated descriptive statistics and graphs. Nonparametric statistical tests were run due to small sample sizes and differences in group size. Kruskal-Wallis and Dunn's Post-Hoc tests compared ${ }^{87} \mathrm{Sr} /{ }^{86} \mathrm{Sr}$ values in several types of bedrock and plant covers. Spearman's rho tests correlated geographical variables and ${ }^{87} \mathrm{Sr} /{ }^{86} \mathrm{Sr}$ values. Wilcoxon Signed Rank tests were used to compare dental tissues of the same tooth with and without acid-treatment, and Mann-Whitney $\mathrm{U}$ tests were used to observe variation between localities where different plant types were collected, and compare enamel and dentine results. These tests were run using PAST 3.19 (https://folk.uio.no/ohammer/past/).

To create our isoscape, sample coordinates were imported in ArcGIS 10.5.1 as point shapefiles. The related database showed ${ }^{87} \mathrm{Sr} /{ }^{86} \mathrm{Sr}$ values associated with each locality. Resulting georeferences for ${ }^{87} \mathrm{Sr} /{ }^{86} \mathrm{Sr}$ values were subject to Empirical Bayesian Krigging (EBK): a random interpolation method that calculates predicted ${ }^{87} \mathrm{Sr} /{ }^{86} \mathrm{Sr}$ ratios across the landscape from known 
291 values. Simulations reached 100 semi-variograms. The results were classified into ten geometric 292 intervals, yielding a regional isoscape.

293 Full datasets are available at the Federated Research Data Repository (doi: 294 10.20383/101.0157) and a preprint of this manuscript has been made available online with the 295 Open Science Framework (doi: xxx).

296

297 4. Results

$298 \quad 4.1$ Bioavailable Strontium

299 4.1.1 Geological variation

$300 \quad$ See Table 4.1 for the full list of ${ }^{87} \mathrm{Sr} /{ }^{86} \mathrm{Sr}$ results for each locality, the geological domain, 301 and the types of plants collected and Figure 4.1 for the isoscape of the region. The range in ${ }^{87} \mathrm{Sr} /{ }^{86} \mathrm{Sr}$ 302 values for all localities was 0.70424 to 0.70476 . Summary statistics for each geological domain 303 are in Table 4.2. There was a significant difference between ${ }^{87} \mathrm{Sr} /{ }^{86} \mathrm{Sr}$ values for localities from 304 differing bedrock types (Kruskal-Wallis Test, $P<0.01$ ), but only between lacustrine ( $\mathrm{n}=5$; 305 median=0.70471) and metamorphic areas (n=9; median=0.70449) (Dunn’s Post-Hoc Test, $P$ $306<0.01)$ and lacustrine and volcanic areas ( $\mathrm{n}=19$; median=0.70449) (Dunn’s Post-Hoc Test, P $307<0.001)$.

308

309 4.1.2 Geographical variation

310 Graphs of ${ }^{87} \mathrm{Sr} /{ }^{86} \mathrm{Sr}$ values plotted against geographic variables are presented in Figure 4.2.

311 See Table 4.3 for Spearman's correlation coefficients describing relationships between 312 geographical variables and ${ }^{87} \mathrm{Sr} /{ }^{86} \mathrm{Sr}$ values. There is a moderate negative correlation between $313{ }^{87} \mathrm{Sr} /{ }^{86} \mathrm{Sr}$ and elevation for all localities (Spearman's correlation, $\mathrm{R}=-0.370$ ). There is no correlation 


\begin{tabular}{|c|c|c|c|}
\hline Locality & ${ }^{87} \mathrm{Sr} /{ }^{86} \mathrm{Sr}$ & $2 \mathrm{SE}^{\mathrm{a}}$ & Plant types collected $^{\mathrm{b}}$ \\
\hline 1 & 0.704539 & 0.000006 & TTG \\
\hline 2 & 0.704513 & 0.000006 & TTT \\
\hline 3 & 0.704523 & 0.000006 & SGG \\
\hline 4 & 0.704324 & 0.000006 & SSG \\
\hline 5 & 0.704241 & 0.000004 & SGG \\
\hline 6 & 0.704443 & 0.000002 & SSG \\
\hline 7 & 0.704381 & 0.000006 & TGG \\
\hline 8 & 0.704563 & 0.000006 & TGG \\
\hline 9 & 0.704427 & 0.000012 & GGG \\
\hline 10 & 0.704402 & 0.000014 & TSS \\
\hline 11 & 0.704493 & 0.000004 & SSS \\
\hline 12 & 0.704268 & 0.000016 & SSG \\
\hline 13 & 0.704485 & 0.000010 & SSS \\
\hline 14 & 0.704648 & 0.000004 & TSG \\
\hline 15 & 0.704435 & 0.000004 & SGG \\
\hline 16 & 0.704555 & 0.000004 & TSG \\
\hline 17 & 0.704379 & 0.000004 & GGG \\
\hline 18 & 0.704630 & 0.000006 & SSG \\
\hline 19 & 0.704490 & 0.000006 & GGG \\
\hline 20 & 0.704488 & 0.000004 & TSS \\
\hline 21 & 0.704488 & 0.000010 & SSG \\
\hline 22 & 0.704476 & 0.000008 & TSS \\
\hline 23 & 0.704639 & 0.000004 & TTG \\
\hline 24 & 0.704738 & 0.000008 & TTT \\
\hline 25 & 0.704714 & 0.000008 & TSG \\
\hline 26 & 0.704758 & 0.000012 & TTS \\
\hline 27 & 0.704684 & 0.000004 & TSS \\
\hline 28 & 0.704375 & 0.000004 & SSS \\
\hline 29 & 0.704601 & 0.000004 & TGG \\
\hline 30 & 0.704518 & 0.000004 & TGG \\
\hline 31 & 0.704599 & 0.000024 & TGG \\
\hline 32 & 0.704477 & 0.000010 & GGG \\
\hline 33 & 0.704480 & 0.000004 & SGG \\
\hline
\end{tabular}

314 Table 4.1: ${ }^{87} \mathrm{Sr} /{ }^{86} \mathrm{Sr}$ results and the type of plants analyzed for each locality.

315 a 2 SE: Standard error is the internal precision of the TIMS measurements for each sample.

316 b Plant type codes: $\mathrm{T}=$ tree, $\mathrm{S}=$ shrub, $\mathrm{G}=$ grass. Small herbs (e.g. Asparagus africanus) are 317 included with grasses, and large succulents (e.g. Aloe secundiflora) are included with shrubs. 


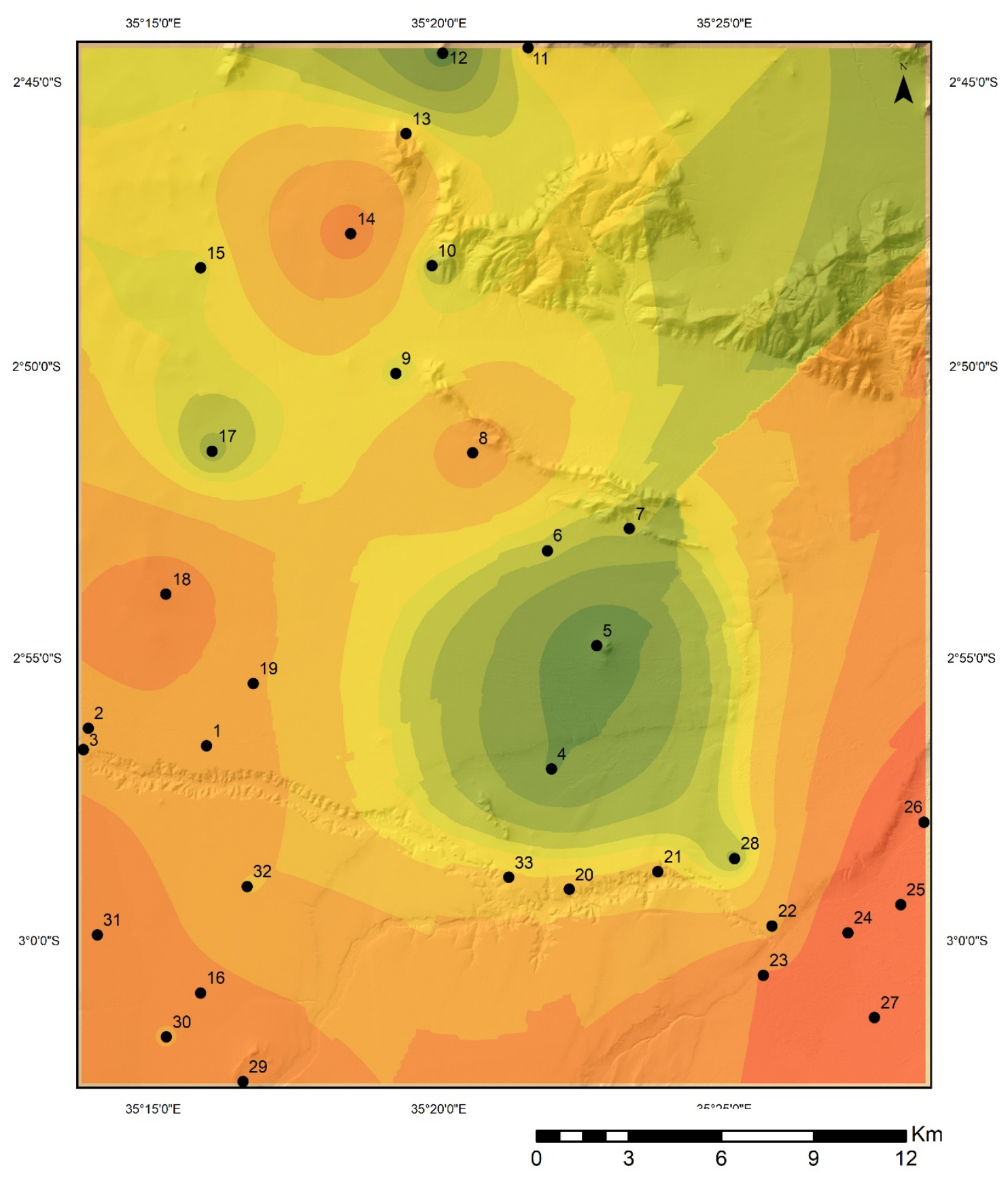

Predicted Values (Empirical Bayesian Kriging)
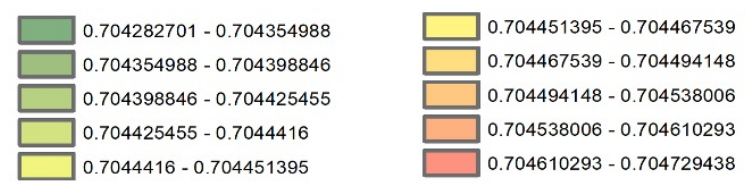

Figure 4.1: Isoscape showing the approximate spatial distribution of bioavailable strontium 321 values across the landscape. 


\begin{tabular}{|l|l|l|l|l|l|l|}
\hline & $\mathrm{N}$ & Mean & Median & Minimum & Maximum & SD \\
\hline Volcanic & 19 & 0.70447 & 0.70449 & 0.70424 & 0.70463 & 0.00001 \\
Metamorphic & 9 & 0.70447 & 0.70449 & 0.70427 & 0.70465 & 0.00012 \\
Lacustrine & 5 & 0.70471 & 0.70471 & 0.70464 & 0.70476 & 0.00001 \\
All & 33 & 0.70451 & 0.70449 & 0.70424 & 0.70476 & 0.00013 \\
\hline
\end{tabular}

323 Table 4.2: Summary statistics of ${ }^{87} \mathrm{Sr} /{ }^{86} \mathrm{Sr}$ values of volcanic, metamorphic, lacustrine, and all 324 localities.

325

326 between elevation and metamorphic areas, volcanic areas, or volcanic and metamorphic combined.

327 The correlation coefficient for Olbalbal was strongly negative (Spearman's correlation, $\mathrm{R}=-0.700$ ).

328 The correlation between ${ }^{87} \mathrm{Sr} /{ }^{86} \mathrm{Sr}$ values and latitude for all localities is significant and 329 moderately negative (Spearman's correlation, $\mathrm{R}=-0.454$ ). A moderately negative correlation exists 330 between latitude and volcanic ${ }^{87} \mathrm{Sr} /{ }^{86} \mathrm{Sr}$ values (Spearman's correlation, $\mathrm{R}=-0.340$ ). There was no 331 correlation between metamorphic localities and latitude. Lacustrine localities and latitude have a 332 strongly positive correlation (Spearman’s correlation, $\mathrm{R}=0.800$ ).

333 Longitude is the strongest geographical predictor of ${ }^{87} \mathrm{Sr} /{ }^{86} \mathrm{Sr}$ values. There was a 334 moderately negative correlation between volcanic ${ }^{87} \mathrm{Sr} /{ }^{86} \mathrm{Sr}$ values and longitude (Spearman's 335 correlation, $\mathrm{R}=-0.540$ ), and for metamorphic localities and longitude (Spearman's correlation, $\mathrm{R}=-$ 336 0.517). When volcanic and metamorphic localities are combined there is a moderately negative 337 correlation (Spearman's correlation, $\mathrm{R}=-0.481$ ). There is a strongly positive correlation between 338 longitude and ${ }^{87} \mathrm{Sr} /{ }^{86} \mathrm{Sr}$ values of lacustrine localities (Spearman's correlation, $\mathrm{R}=0.700$ ). There 339 was not a significant correlation when all localities were combined.

\section{$341 \quad$ 4.1.3 Variation between plant types}

The range of ${ }^{87} \mathrm{Sr} /{ }^{86} \mathrm{Sr}$ values for each type of vegetation at localities where they were 343 collected versus localities in which they were not is in Figure 4.3. For only metamorphic and

344 volcanic areas, see Figure 4.4. There was a significant difference in ${ }^{87} \mathrm{Sr} /{ }^{86} \mathrm{Sr}$ value medians 

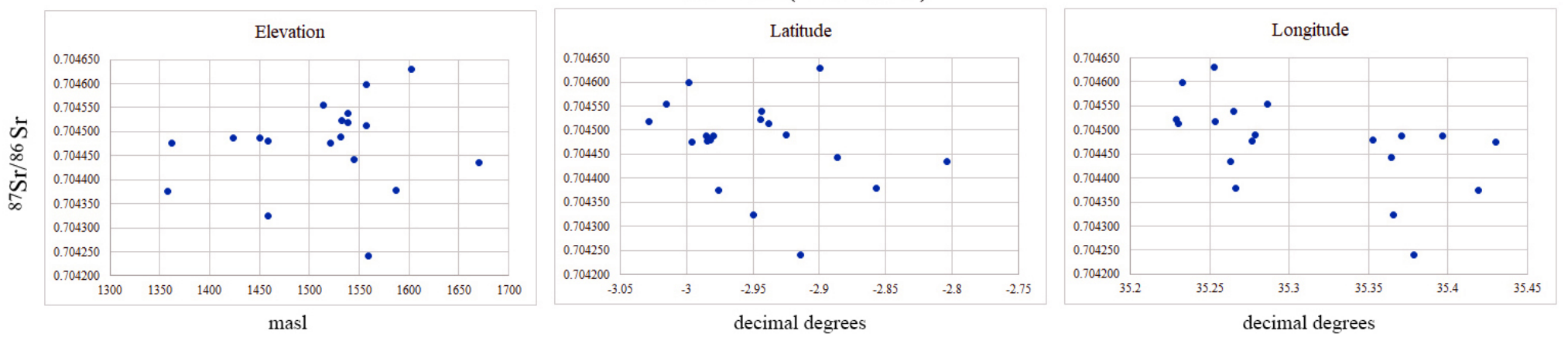

\section{${ }^{87} \mathrm{Sr} /{ }^{86} \mathrm{Sr}$ (Metamorphic)}
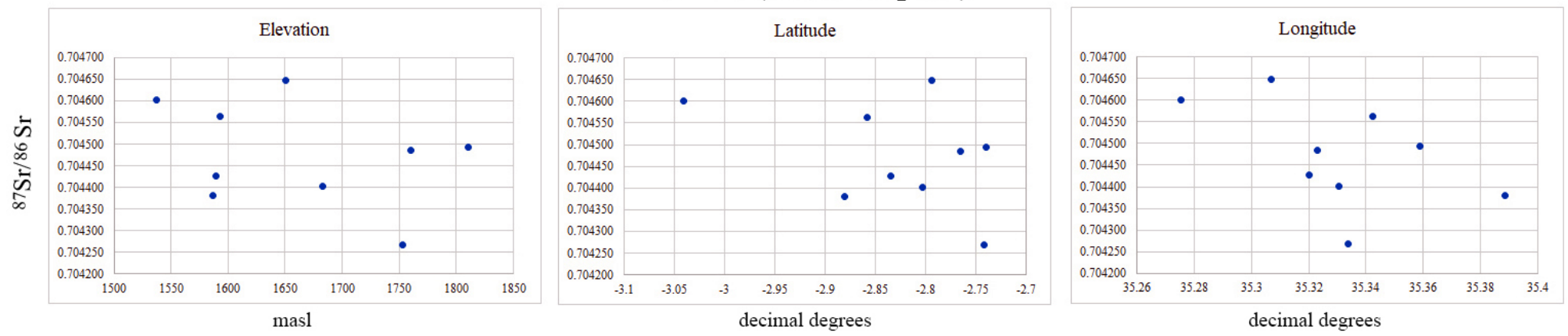

346

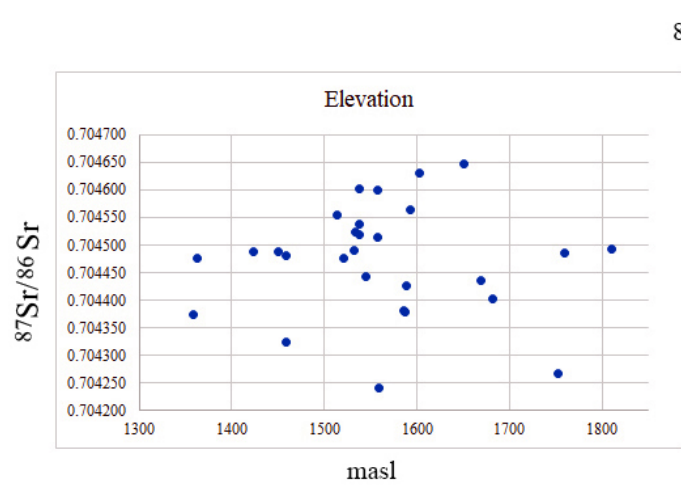

${ }^{87} \mathrm{Sr} /{ }^{86} \mathrm{Sr}$ (Volcanic and Metamorphic)
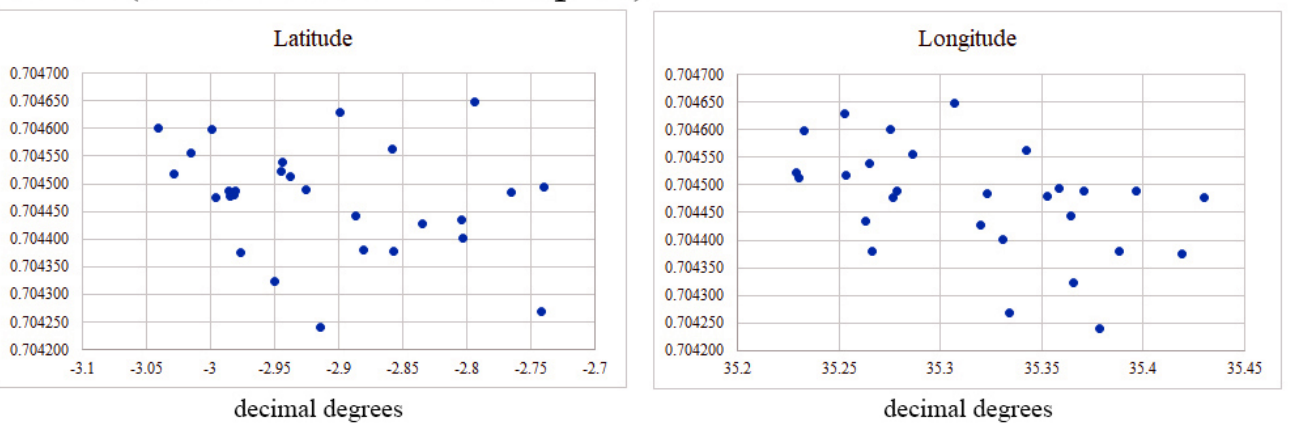

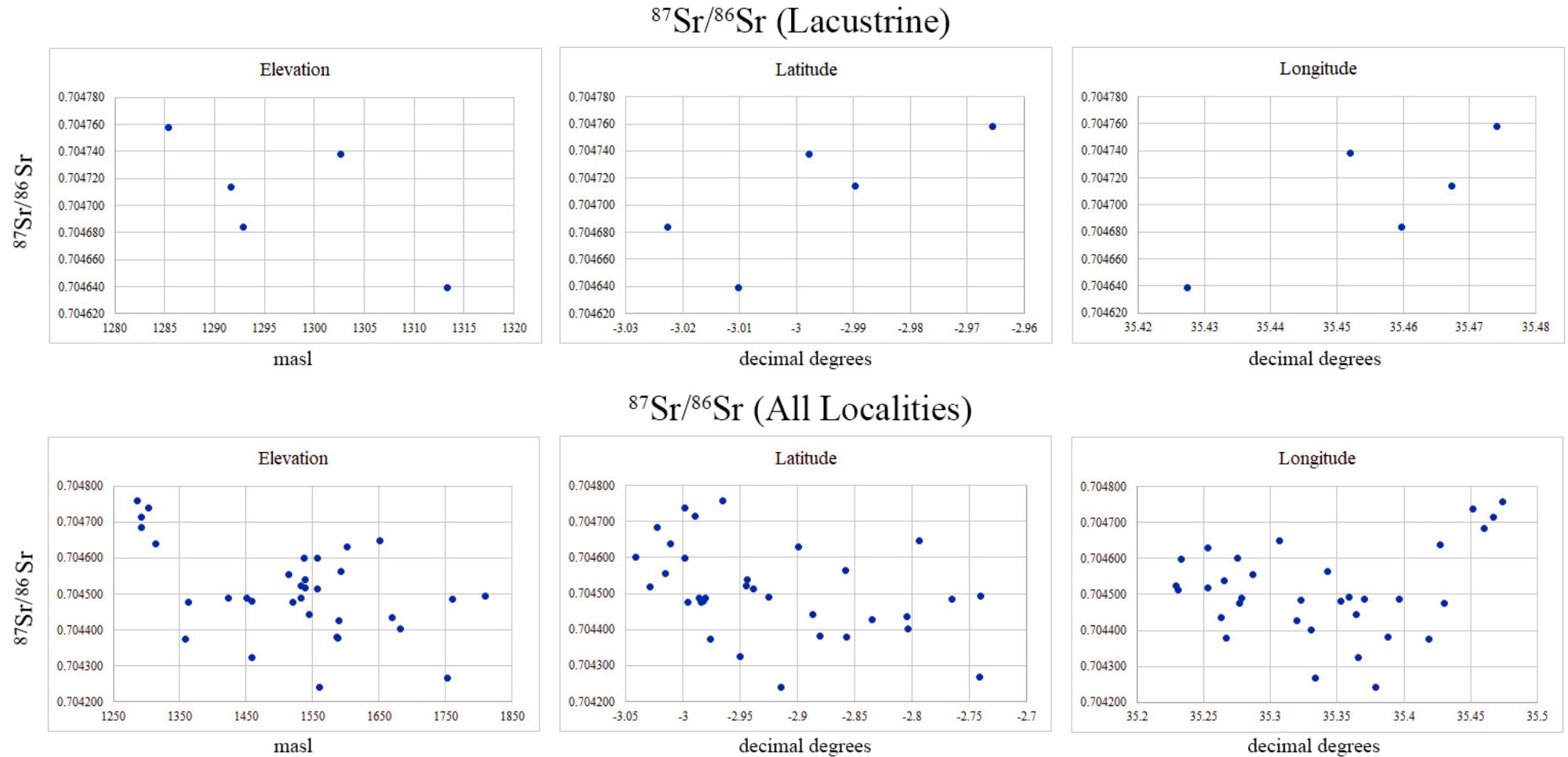

349

Figure 4.2: Graphs of ${ }^{87} \mathrm{Sr} /{ }^{86} \mathrm{Sr}$ for each geological domain plotted against the various geographic variables.

between localities where trees were sampled ( $n=17$; median=0.70456; see Table 4.4) and where only grasses and shrubs were sampled (n=16; median=0.70446) (Mann-Whitney U Test, $P<0.01)$.

All lacustrine samples $(n=5)$ included trees, and all but one had higher ${ }^{87} \mathrm{Sr} /{ }^{86} \mathrm{Sr}$ than any other locality, so the test was re-run with only metamorphic and volcanic localities. There was still a significant difference between localities where trees were sampled (n=12; median=0.70453) and where they were not (n=16; median=0.70446) (Mann-Whitney U Test, $P<0.05)$. There was not a 


\begin{tabular}{|l|l|l|l|l|l|l|l|}
\hline & & \multicolumn{2}{|c|}{ Elevation } & \multicolumn{2}{c|}{ Latitude } & \multicolumn{2}{c|}{ Longitude } \\
\cline { 2 - 7 } & $\mathrm{N}$ & Coefficient & $P$ & Coefficient & $P$ & Coefficient & $P$ \\
\hline All Localities & 33 & $-0.38^{*}$ & $<0.04^{*}$ & $-0.46^{*}$ & $<0.01^{*}$ & -0.07 & 0.72 \\
Volcanic & 19 & 0.15 & 0.55 & $-0.34^{*}$ & 0.15 & $-0.54^{*}$ & $<0.02^{*}$ \\
Metamorphic & 9 & -0.15 & 0.68 & -0.17 & 0.64 & $-0.52^{*}$ & 0.16 \\
Lacustrine & 5 & $-0.70^{*}$ & 0.23 & $0.80^{*}$ & 0.08 & $0.70^{*}$ & 0.23 \\
Volcanic and & 28 & 0.02 & 0.93 & -0.28 & 0.14 & $-0.54^{*}$ & $<0.01^{*}$ \\
Metamorphic & & & & & & & \\
\hline
\end{tabular}

357 Table 4.3: Spearman’s correlation coefficients describing relationships between ${ }^{87} \mathrm{Sr} /{ }^{86} \mathrm{Sr}$ values 358 and geographic variables.

$359 *$ Significant results $(\alpha=0.05)$ and correlations stronger than $|0.3|$

360

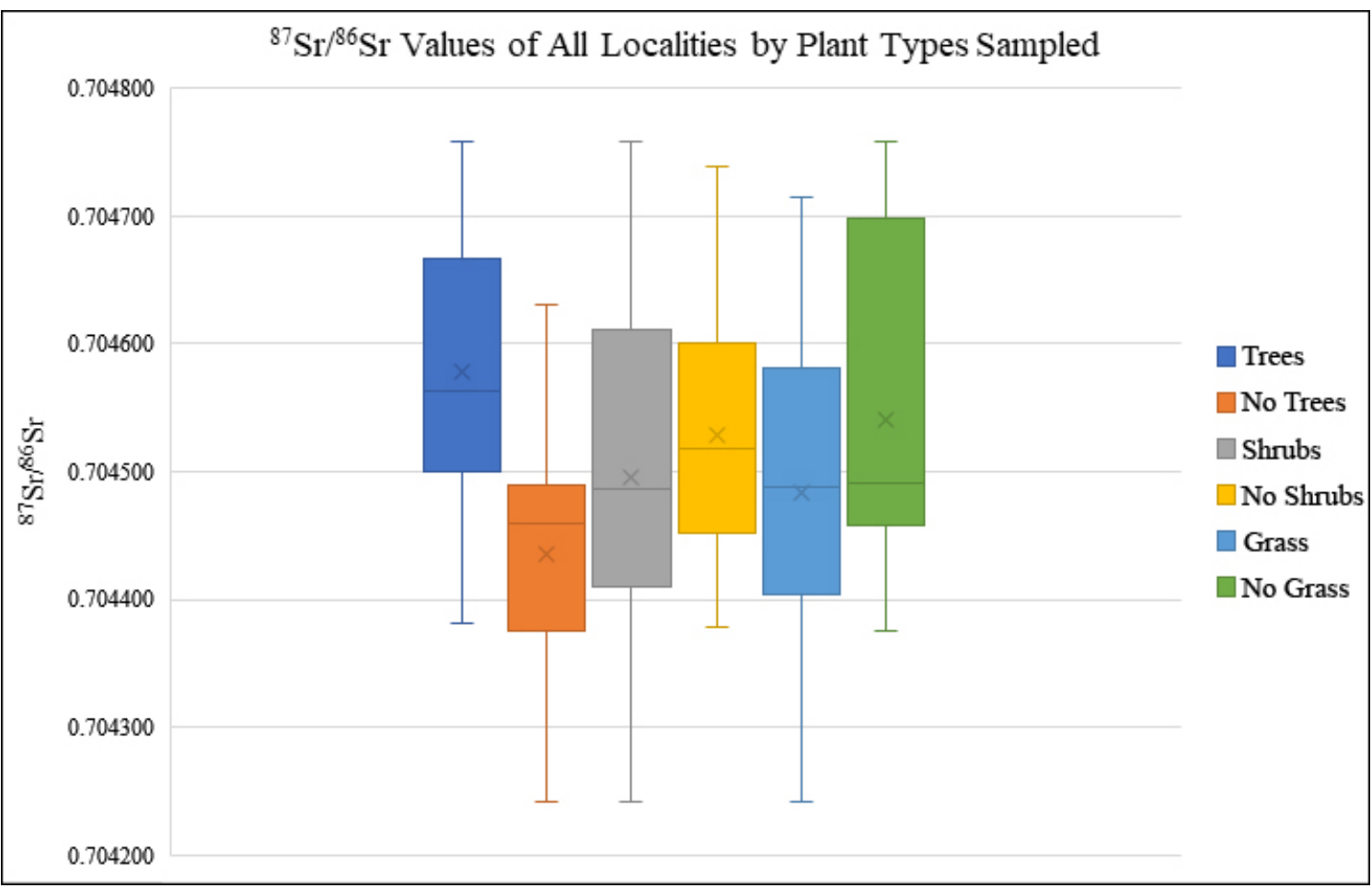

Figure 4.3: Range of ${ }^{87} \mathrm{Sr} /{ }^{86} \mathrm{Sr}$ for each type of vegetation at localities where they were collected versus where that type was not.

significant difference between shrubs and no shrubs or grass and no grass at all localities or only metamorphic and volcanic areas.

There was a significant difference in median ${ }^{87} \mathrm{Sr} /{ }^{86} \mathrm{Sr}$ values between localities of all types where trees were sampled $(n=9 ;$ median=0.70456) and where shrubs were sampled $(n=12$; median=0.70446) (Mann-Whitney U Test; $P<0.01$; see Table 4.5) Localities where both were 


\subsection{Dental Results}

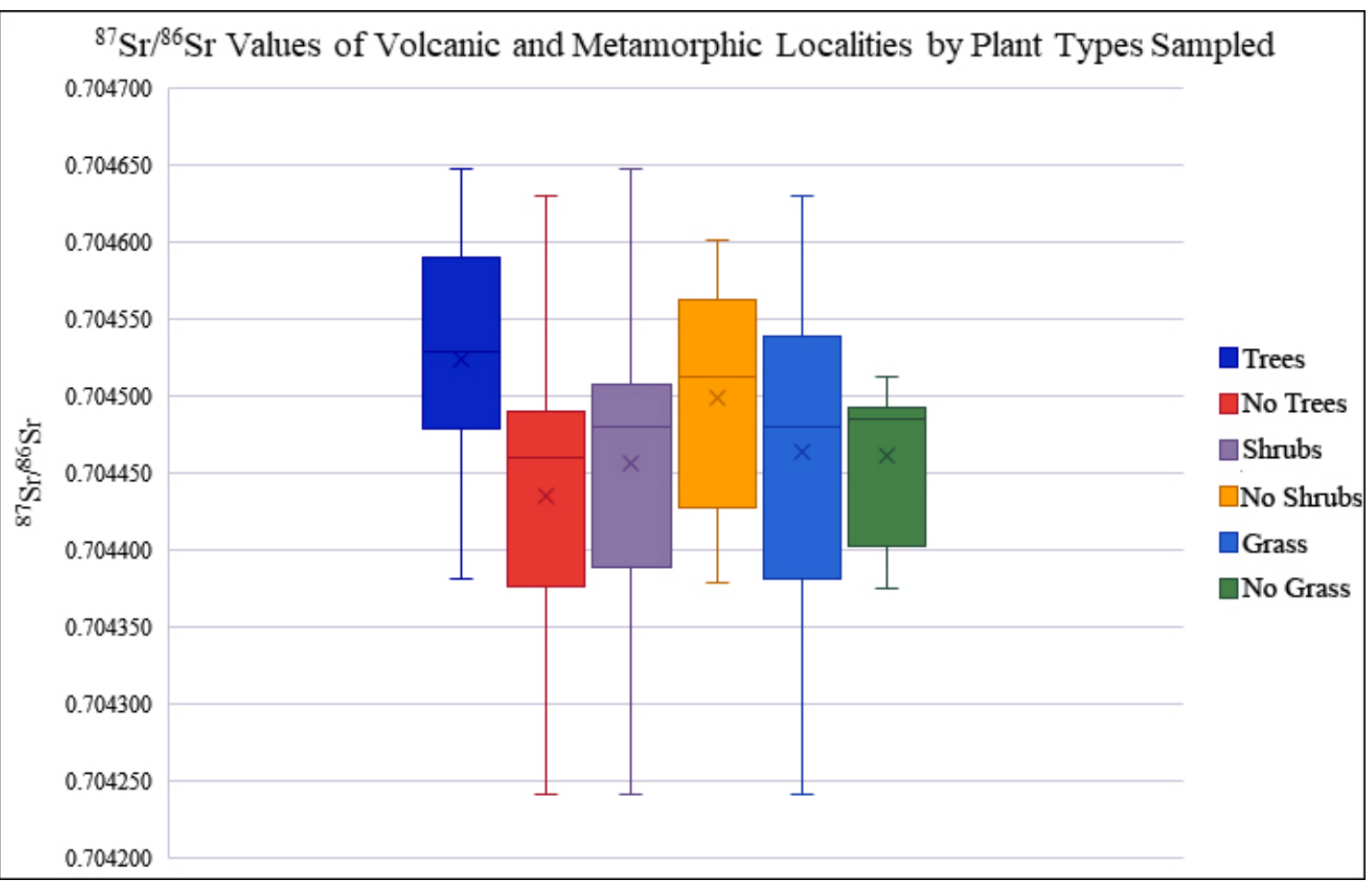

Figure 4.4: ${ }^{87} \mathrm{Sr} /{ }^{86} \mathrm{Sr}$ for each type of vegetation at localities where they were collected versus where they were not (volcanic and metamorphic only).

sampled were excluded from this analysis. The result is not significant when only metamorphic and volcanic localities are examined. There was no significant difference between localities with shrubs and grasses for all localities and metamorphic and volcanic localities, nor for trees and grasses for either condition. When overlapping localities are included, there is no significant difference between medians of ${ }^{87} \mathrm{Sr} /{ }^{86} \mathrm{Sr}$ values where trees, shrubs, and grasses were collected (Kruskal-Wallis Test; $\mathrm{P}=0.084$ ). When lacustrine samples are excluded from this test the result is not significant either (Kruskal-Wallis Test; $P=0.173$ ). For these analyses, herbs were included with grasses, and large succulents were included with shrubs. 


\begin{tabular}{|c|c|c|c|c|c|c|c|c|}
\hline \multicolumn{9}{|c|}{ All Localities } \\
\hline \multicolumn{9}{|c|}{${ }^{87} \mathrm{Sr} /{ }^{86} \mathrm{Sr}$} \\
\hline $\begin{array}{l}\text { Plant } \\
\text { Type }\end{array}$ & $\mathrm{N}$ & Mean & Median & $\mathrm{SD}$ & Minimum & Maximum & Z-score & $P$ \\
\hline Trees & 17 & 0.704577 & 0.704563 & 0.000111 & 0.704381 & 0.704758 & 3.31 & $<0.01^{*}$ \\
\hline No Trees & 16 & 0.704435 & 0.704460 & 0.000010 & 0.704241 & 0.704630 & & \\
\hline Shrubs & 20 & 0.704496 & 0.704487 & 0.000140 & 0.704379 & 0.704758 & -0.83 & 0.41 \\
\hline No Shrubs & 13 & 0.704528 & 0.704518 & 0.000103 & 0.704241 & 0.704738 & & \\
\hline Grasses & 23 & 0.704484 & 0.704490 & 0.000122 & 0.704241 & 0.704714 & -0.72 & 0.47 \\
\hline $\begin{array}{l}\text { No } \\
\text { Grasses }\end{array}$ & 10 & 0.704541 & 0.704491 & 0.000136 & 0.704375 & 0.704758 & & \\
\hline \multicolumn{9}{|c|}{ Metamorphic and Volcanic Only } \\
\hline \multicolumn{9}{|c|}{${ }^{87} \mathrm{Sr} /{ }^{86} \mathrm{Sr}$} \\
\hline $\begin{array}{l}\text { Plant } \\
\text { Type }\end{array}$ & $\mathrm{N}$ & Mean & Median & SD & Minimum & Maximum & Z-score & $P$ \\
\hline Trees & 12 & 0.704524 & 0.704529 & 0.000008 & 0.704381 & 0.704648 & -2.41 & $<0.02 *$ \\
\hline No Trees & 16 & 0.704435 & 0.704460 & 0.000010 & 0.704241 & 0.704630 & & \\
\hline Shrubs & 17 & 0.704456 & 0.70448 & 0.000111 & 0.704241 & 0.704648 & -1.13 & 0.26 \\
\hline No Shrubs & 11 & 0.704499 & 0.704513 & 0.000008 & 0.704379 & 0.704601 & & \\
\hline Grasses & 19 & 0.704471 & 0.704484 & 0.000010 & 0.704241 & 0.704630 & 0.40 & 0.75 \\
\hline $\begin{array}{l}\text { No } \\
\text { Grasses }\end{array}$ & 7 & 0.704462 & 0.704485 & 0.000005 & 0.704375 & 0.704513 & & \\
\hline
\end{tabular}

Table 4.4: Mann-Whitney U Test results and summary statistics for plant types vs. localities where they were not collected.

$*$ Results significant $(\alpha=0.05)$

All dental ${ }^{87} \mathrm{Sr} /{ }^{86} \mathrm{Sr}$ values were higher than any bioavailable strontium results (range=0.705130.70547) (Figure 4.5; Table 4.6). There was a significant difference between the median ${ }^{87} \mathrm{Sr} /{ }^{86} \mathrm{Sr}$ values of acid-treated enamel (median=0.70530) and dentine (median=0.70534) (Wilcoxon Signed Rank Test, $\mathrm{P}<0.05$; Table 4.7). There were no significant differences between any other tissues in either condition.

Enamel ${ }^{87} \mathrm{Sr} /{ }^{86} \mathrm{Sr}$ values changed the most with acid for EN1 (difference=0.000257). For all other teeth the absolute difference in ${ }^{87} \mathrm{Sr} /{ }^{86} \mathrm{Sr}$ values of enamel was 0.000038 or less, averaging 0.000054 when EN1 is included and 0.000020 when it is not. Dentine had larger differences between acid-treated and non acid-treated samples. EN1 again had the largest absolute difference (0.000240), followed by EN3 (0.000181). The average absolute difference in dentine was 


\begin{tabular}{|c|c|c|c|c|c|c|c|c|}
\hline \multicolumn{9}{|c|}{ All Localities } \\
\hline \multicolumn{9}{|c|}{${ }^{87} \mathrm{Sr} /{ }^{86} \mathrm{Sr}$} \\
\hline $\begin{array}{l}\text { Plant } \\
\text { Type }\end{array}$ & $\mathrm{N}$ & Mean & Median & $\mathrm{SD}$ & Minimum & Maximum & $\begin{array}{l}\text { Z- } \\
\text { score }\end{array}$ & $P$ \\
\hline Trees & 9 & 0.704566 & 0.704563 & 0.000010 & 0.704381 & 0.704738 & -2.67 & $<0.01^{*}$ \\
\hline Shrubs & 12 & 0.704432 & 0.704462 & 0.000003 & 0.704241 & 0.704630 & & \\
\hline Trees & 7 & 0.704580 & 0.704513 & 0.000143 & 0.704402 & 0.704758 & -1.94 & 0.05 \\
\hline Grass & 13 & 0.704431 & 0.704443 & 0.000107 & 0.704241 & 0.704630 & & \\
\hline Shrubs & 8 & 0.704520 & 0.704487 & 0.000133 & 0.704375 & 0.704758 & -0.29 & 0.77 \\
\hline Grass & 11 & 0.704510 & 0.704518 & 0.000009 & 0.704379 & 0.704639 & & \\
\hline \multicolumn{9}{|c|}{ Metamorphic and Volcanic Only } \\
\hline & & & & ${ }^{87} \mathrm{Sr} /{ }^{86}$ & & & & \\
\hline $\begin{array}{l}\text { Plant } \\
\text { Type }\end{array}$ & $\mathrm{N}$ & Mean & Median & SD & Minimum & Maximum & $\begin{array}{l}\text { Z- } \\
\text { score }\end{array}$ & $P$ \\
\hline Trees & 7 & 0.704531 & 0.704539 & 0.000007 & 0.704381 & 0.704601 & -2.16 & $<0.01 *$ \\
\hline Shrubs & 12 & 0.704432 & 0.704462 & 0.000003 & 0.704241 & 0.704630 & & \\
\hline Trees & $4^{\ddagger}$ & 0.704470 & 0.704482 & 0.000005 & 0.704402 & 0.704513 & n.d. & n.d. \\
\hline Grass & 13 & 0.704431 & 0.704443 & 0.000107 & 0.704241 & 0.704630 & & \\
\hline Shrubs & 6 & 0.704453 & 0.704481 & 0.000005 & 0.704375 & 0.704493 & -1.25 & 0.212 \\
\hline Grass & 10 & 0.704497 & 0.704504 & 0.000008 & 0.704379 & 0.704601 & & \\
\hline
\end{tabular}

0.000094 when EN1 is included and 0.000070 when it is not. Including EN1, the average change in dentine was almost double that of enamel, and when excluded the average change is more than triple that of enamel. Enamel ${ }^{87} \mathrm{Sr} /{ }^{86} \mathrm{Sr}$ values increased after acid treatment except EN5 and EN7. Dentine ${ }^{87} \mathrm{Sr} /{ }^{86} \mathrm{Sr}$ values changed more unexpectedly, with four decreases and three increases.

The highest (0.70543) and lowest (0.70513) acid-treated enamel values were crocodiles, and the hippopotamus is between the crocodile and equid values (Table 4.8). Thus, there appears to be no difference between aquatic and terrestrial fauna. 
413

414 415

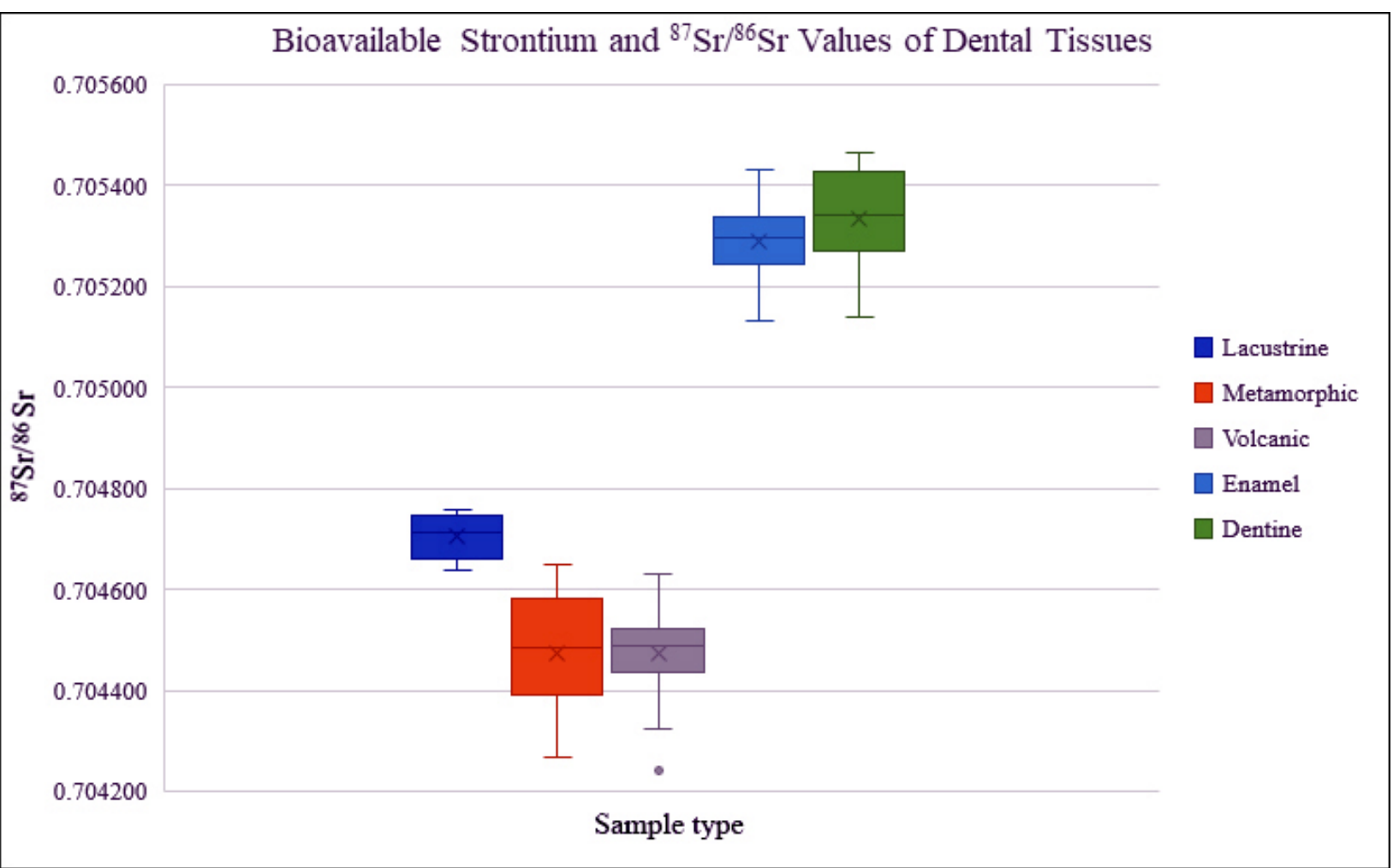

Figure 4.5: Acid-washed dental ${ }^{87} \mathrm{Sr} /{ }^{86} \mathrm{Sr}$ values versus bioavailable values

\begin{tabular}{|c|c|c|c|c|}
\hline \multicolumn{5}{|c|}{ Enamel ${ }^{87} \mathrm{Sr} /{ }^{86} \mathrm{Sr}$} \\
\hline Tooth & Family & Acid & No Acid & Difference \\
\hline EN1 & Equidae & 0.705339 & 0.705082 & 0.000257 \\
\hline EN2 & Crocodylidae & 0.705245 & 0.705207 & 0.000038 \\
\hline EN3 & Crocodylidae & 0.705296 & 0.705264 & 0.000032 \\
\hline EN4 & Crocodylidae & 0.705433 & 0.705412 & 0.000021 \\
\hline EN5 & Crocodylidae & 0.705133 & 0.705143 & -0.000010 \\
\hline EN6 & Equidae & 0.705252 & 0.705246 & 0.000006 \\
\hline EN7 & Hippopotamidae & 0.705313 & 0.705324 & -0.000011 \\
\hline \multicolumn{5}{|c|}{ Dentine ${ }^{87} \mathrm{Sr} /{ }^{86} \mathrm{Sr}$} \\
\hline Tooth & Family & Acid & No Acid & Difference \\
\hline EN1 & Equidae & 0.705466 & 0.705226 & 0.000240 \\
\hline EN2 & Crocodylidae & 0.705270 & 0.705329 & -0.000059 \\
\hline EN3 & Crocodylidae & 0.705428 & 0.705237 & 0.000191 \\
\hline EN4 & Crocodylidae & 0.705415 & 0.705423 & -0.000008 \\
\hline EN5 & Crocodylidae & 0.705138 & 0.705185 & -0.000047 \\
\hline EN6 & Equidae & 0.705289 & 0.705200 & 0.000089 \\
\hline EN7 & Hippopotamidae & 0.705340 & 0.705367 & -0.000027 \\
\hline
\end{tabular}

416 Table 4.6: ${ }^{87} \mathrm{Sr} /{ }^{86} \mathrm{Sr}$ results for the acid washing experiment. The difference column is calculated 417 as difference $=$ acid - no acid. 


\begin{tabular}{|l|l|l|l|l|l|}
\hline \multicolumn{1}{|c|}{ Tissue } & \multicolumn{1}{|c|}{$\mathrm{N}$} & \multicolumn{1}{c|}{ Median } & \multicolumn{1}{c|}{ Z-score } & W-value & p-value \\
\hline Enamel (A) & 7 & 0.705296 & -1.521 & 23 & 0.12819 \\
Enamel (N) & 7 & 0.705246 & & & \\
Dentine (A) & 7 & 0.705340 & 0.6761 & 18 & 0.49896 \\
Dentine (N) & 7 & 0.705237 & & & \\
Enamel (A) & 7 & 0.705296 & 2.0284 & 26 & $\mathbf{0 . 0 4 2 5 2}$ \\
Dentine (A) & 7 & 0.705340 & & & \\
Enamel (N) & 7 & 0.705246 & 1.1832 & 21 & 0.23672 \\
Dentine (N) & 7 & 0.705237 & & & \\
Both (A) & 14 & 0.7053045 & 1.1614 & 71 & 0.24549 \\
Both (N) & 14 & 0.7052415 & & & \\
\hline
\end{tabular}

420 Table 4.7: Wilcoxon Signed Rank test results from the acid treatment experiment. Significant 421 results are bolded $(\alpha=0.05) . \mathrm{A}=$ acid, $\mathrm{N}=$ no acid.

422

\begin{tabular}{|l|l|l|l|l|l|}
\hline \multicolumn{7}{|c|}{ Enamel ${ }^{\mathbf{8 7}} \mathbf{S r} /{ }^{\mathbf{8 6}} \mathbf{S r}$} \\
\hline \multicolumn{1}{|c|}{ Family } & $\mathrm{N}$ & \multicolumn{1}{|c|}{ Minimum } & Maximum & Mean & SD \\
\hline Equidae & 2 & 0.705252 & 0.705339 & 0.705296 & 0.000006 \\
Crocodylidae & 4 & 0.705143 & 0.705433 & 0.705277 & 0.000124 \\
Hippopotamidae & 1 & 0.705313 & 0.705313 & 0.705313 & N/A \\
\hline \multicolumn{7}{|c|}{ Dentine ${ }^{\mathbf{8 7}} \mathbf{S r} /{ }^{\mathbf{8 6}} \mathbf{S r}$} \\
\hline \multicolumn{7}{|c|}{ Family } & $\mathrm{N}$ & Minimum & Maximum & Mean & SD \\
\hline Equidae & 2 & 0.705289 & 0.705466 & 0.705378 & 0.000125 \\
Crocodylidae & 4 & 0.705138 & 0.705428 & 0.705313 & 0.000137 \\
Hippopotamidae & 1 & 0.705340 & 0.705340 & 0.705340 & N/A \\
\hline
\end{tabular}

423 Table 4.8: Descriptive statistics for acid-washed dental ${ }^{87} \mathrm{Sr} /{ }^{86} \mathrm{Sr}$ results by family.

424

$425 \quad$ 5. Discussion

$426 \quad 5.1 \quad$ Sources of Variation

$427 \quad 5.1 .1$ Bedrock

There was a small range in ${ }^{87} \mathrm{Sr} /{ }^{86} \mathrm{Sr}$ values, despite sampling over approximately $750 \mathrm{~km}{ }^{2}$

429 and varying geology. Therefore, it will be easy to see animals from outside the area, but difficult

430 to trace movement within the region. ${ }^{87} \mathrm{Sr} /{ }^{86} \mathrm{Sr}$ values of metamorphic inselbergs and volcanic areas

431 were statistically indistinguishable from one another. The metamorphic rocks are either similar

432 isotopically to the volcanic ones, or atmospheric strontium obscures their differences. The 
433 Mozambique Belt rocks are likely more radiogenic than the volcanics, so atmospheric strontium

434 likely provides much of the bioavailable strontium reservoir.

435

$436 \quad$ 5.1.2 Atmospheric strontium

437 Oldupai receives rain in the wet season, though it likely has low strontium concentrations

438 (Andersson et al., 1990; Stewart et al., 2001). Mean annual rainfall is about $50 \mathrm{~cm}$ and precipitation 439 evaporates rapidly (Hay, 1976), so rain is probably not a significant contributor of strontium. Dust

440 storms are common and a likely contributor of strontium, potentially leading to homogeneity in

441 bioavailable strontium. Wind is typically easterly, carrying ash from Oldoinyo Lengai and loosely442 packed soil constituted largely of volcanic ash (Anderson and Talbot, 1965).

443

$444 \quad$ 5.1.3 Hydrological strontium

445 Rivers may have different ${ }^{87} \mathrm{Sr} /{ }^{86} \mathrm{Sr}$ values than the rest of the landscape (Wadleigh et al., 446 1985; Palmer and Edmond, 1989). Olbalbal has higher ${ }^{87} \mathrm{Sr} /{ }^{86} \mathrm{Sr}$ values than all but one locality.

447 The Oldupai river ends there and is likely carrying strontium from Lakes Masek and Ndutu, the 448 volcanic landscape in between, and riverbed basalts from Ngorongoro (Hay, 1976). Ngorongoro 449 lavas have ${ }^{87} \mathrm{Sr} /{ }^{86} \mathrm{Sr}$ values ranging from $\sim 0.704$ to 0.708 (Mollel et al., 2008; 2011; Figure 5.1). 450 As well, the Tanzania Craton is highly radiogenic, possibly contributing strontium to the river via 451 groundwater or dust (Copeland et al., 2012).

452

\section{$453 \quad 5.1 .4 \quad$ Geographical factors}

454

Areas of high elevation experience increased weathering and often have ${ }^{87} \mathrm{Sr} /{ }^{86} \mathrm{Sr}$ ratios 455 closer to bedrock than atmospheric values, particularly in rivers (Bentley, 2006; Brennan et al., 


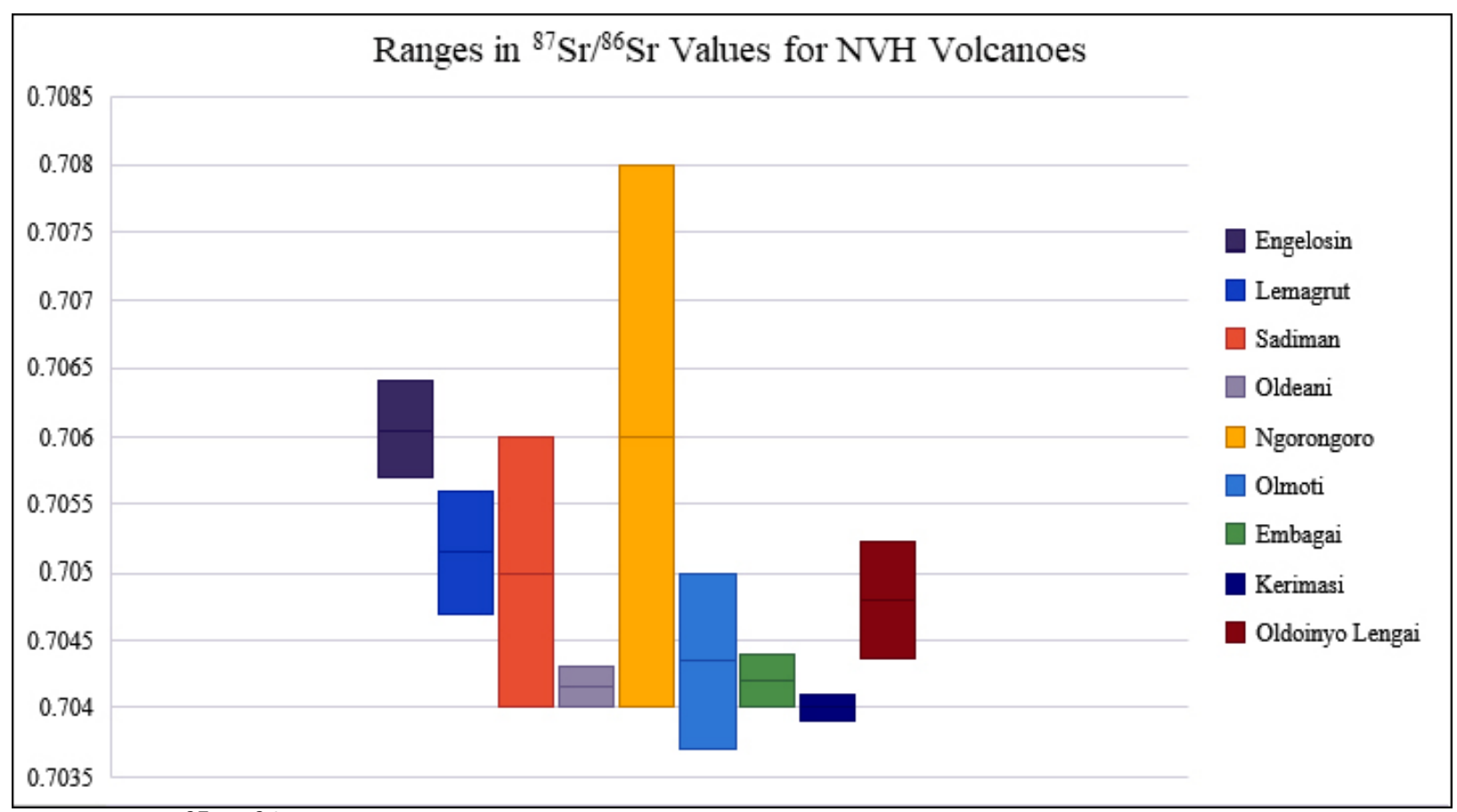

Figure 5.1: ${ }^{87} \mathrm{Sr} /{ }^{86} \mathrm{Sr}$ values for various materials from volcanoes of the Ngorongoro Volcanic 458 Highland.

2016). A weak negative correlation exists between elevation and ${ }^{87} \mathrm{Sr} /{ }^{86} \mathrm{Sr}$ values when all 461 localities were included, likely driven by the lacustrine samples. Lower parts of Olbalbal hold river 462 water for longer, so plants growing there receive more water. One water source is stream water 463 from Lemagrut, approximately 1,500 $\mathrm{m}$ in height (Hay, 1976) and likely weathered faster than 464 lower areas. Its ${ }^{87} \mathrm{Sr} /{ }^{86} \mathrm{Sr}$ values are $\sim 0.7047$ to 0.7052 (Mollel et al., 2011), so the stream is 465 probably partly responsible Olbalbal’s values.

A negative relationship between exists latitude and ${ }^{87} \mathrm{Sr} /{ }^{86} \mathrm{Sr}$ for all localities except

467 Olbalbal, but longitude is a stronger predictor. No correlation exists between ${ }^{87} \mathrm{Sr} /{ }^{86} \mathrm{Sr}$ values and 468 longitude for all localities, likely due to Olbalbal as this test responds only to monotonic 469 relationships. These trends for metamorphic and volcanic localities may be caused by Oldoinyo 470 Lengai. Its extrusions have ${ }^{87} \mathrm{Sr} /{ }^{86} \mathrm{Sr}$ values of $\sim 0.70412$ to 0.70522 , though most had values less 471 than 0.70450 (Bell and Simonetti, 1996; Kalt et al., 1997). These values are close to the 
472 bioavailable ones, particularly in the north and east. It may therefore possible to identify animals 473 or hominins that originated near the volcano.

474

$475 \quad 5.1 .5 \quad$ Plant types

476 Ligneous plants have deeper roots and use more bedrock strontium, whereas shallower477 rooted plants may use more atmospheric strontium (Whipkey et al., 2000; Maurer et al., 2012; 478 Hartman and Richards, 2014). Localities with trees had higher ${ }^{87} \mathrm{Sr} /{ }^{86} \mathrm{Sr}$ values (descriptive 479 statistics; tree mean $=0.70458$, shrub mean $=0.70450$, grass mean=0.70448), so bedrock strontium 480 may be more radiogenic than atmospheric strontium. We attempted to collect a grass, shrub, and 481 tree from every locality in case of differences between plant types, but this was impossible due to 482 homogeneity of flora in some areas (Figure 5.2).

483

$484 \quad 5.2$ Dental Tissues

$485 \quad$ 5.2.1 Diagenesis

486 Untreated enamel and dentine ${ }^{87} \mathrm{Sr} /{ }^{86} \mathrm{Sr}$ values from the same tooth did not differ 487 significantly from one another. However, dentine ${ }^{87} \mathrm{Sr} /{ }^{86} \mathrm{Sr}$ values were significantly higher than 488 enamel values when acid treated. On average, dentine ${ }^{87} \mathrm{Sr} /{ }^{86} \mathrm{Sr}$ values changed more than enamel, 489 suggesting they were more altered. However, changes were small, so diagenesis may not be strong 490 at the site. Copeland et al. (2012) found similar ${ }^{87} \mathrm{Sr} /{ }^{86} \mathrm{Sr}$ results for most Bed I fauna, ranging $491 \sim 0.70450-0.70650$. Consistency in values from Bed I to Bed III but with interindividual variation 492 suggests that biogenic values are preserved. 


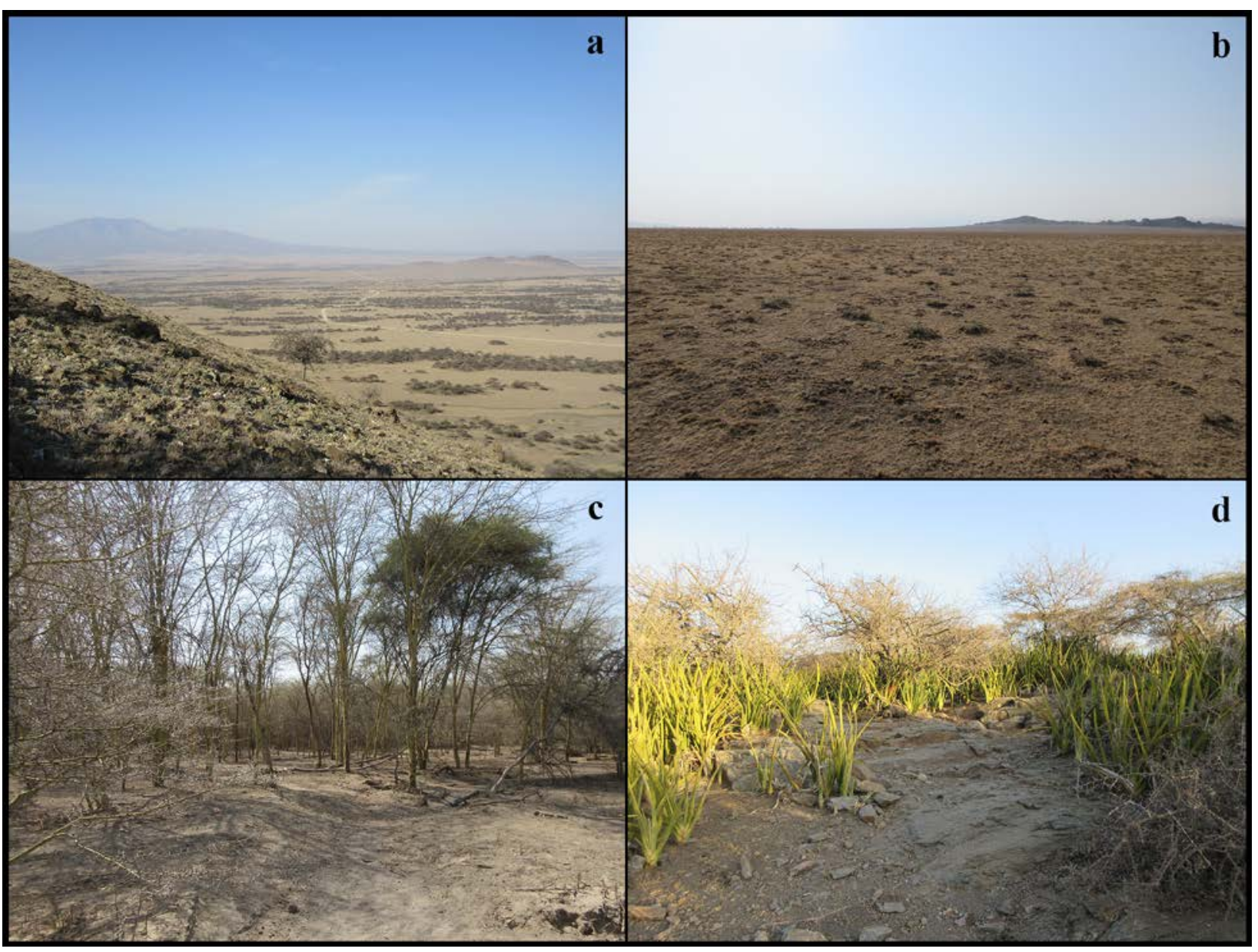

Figure 5.2: Plant landscapes near Oldupai Gorge; a) an elevated view of Lemagrut (left) and Naibor Soit (right) facing southwest from near the top of Engelosin showing patchy wooded areas (uphill from Locality 5); b) open grassland showing sparse covering with short grasses northwest of Naibor Soit (Locality 30); c) a patch of Acacia xanthophloea on the outskirts of the Olbalbal depression (Locality 26); d) Sansevieria robusta and Commiphora merkeri at Granite Falls, the western limit of Oldupai Gorge (Locality 3).

\subsubsection{Taxonomy and migration}

Dental results were higher than bioavailable values. Crocodiles were most variable ranges are less than $30 \mathrm{~km}^{2}$ (Caverley and Downs, 2015), though they may hunt non-local prey and have unusual ${ }^{87} \mathrm{Sr} /{ }^{86} \mathrm{Sr}$ ratios. This variation is probably not from land use, unless some teeth were transported fluvially from elsewhere. Rather, it could be from consuming different prey. The crocodiles also may have lived at different times, as EN spans $315 \mathrm{ka}$ and the stratigraphy is not 
509 well-dated. Hippopotamus (Hippopotamus amphibius) are semi-aquatic, are rarely more than 2-3

$510 \mathrm{~km}$ from water, and eat primarily herbivorous foods (Bakker et al., 2016). Therefore, they should

511 yield local ${ }^{87} \mathrm{Sr} /{ }^{86} \mathrm{Sr}$ values. The hippopotamus sampled had a ${ }^{87} \mathrm{Sr} /{ }^{86} \mathrm{Sr}$ ratio of 0.70531 , which

512 was higher than all but one zebra and one crocodile.

513 Zebras (Equus quagga) migrate up to $500 \mathrm{~km}$ seasonally (Lee et al., 2016; Naidoo et al.,

514 2016). The zebra teeth analysed here are close to the hippopotamus; therefore, appearing local.

515 Most zebras today migrate north to the Serengeti (Estes, 2014), though some are resident.

516 Copeland et al. (2012) found that the northern and western parts of the Serengeti have high

$517{ }^{87} \mathrm{Sr} /{ }^{86} \mathrm{Sr}$ values, but $\sim 80 \mathrm{~km}$ northwest of Oldupai had bioavailable strontium values like those

518 found here. If zebras were migrating within this area, they would be indistinguishable from

519 residents. Alternatively, they may have been sedentary in the past. In Bed III times EN may have

520 been wet enough to support animals year-round, or they may not have travelled as far for resources.

521 No Bed I Antilopini and Alcelophini had non-local ${ }^{87} \mathrm{Sr} /{ }^{86} \mathrm{Sr}$ ratios (Copeland et al., 2012), so

522 environmental differences in the past may have allowed animals to be resident. If so, non-local

$523{ }^{87} \mathrm{Sr} /{ }^{86} \mathrm{Sr}$ values may indicate dispersal rather than migration.

524

$525 \quad 5.3$ Modern vs. Ancient Bioavailable Strontium

526 Bioavailable strontium in the past may have been different, as the archaeological values do 527 not align with the modern plants, possibly due to the environment because the region was wetter 528 than the present in Bed III times (Kleindienst, 1973). Rainwater sources may have been different; 529 for example: Lake Victoria formed about $50 \mathrm{ka}$ and is a source of meteoric water around Oldupai 530 today, but it was not around in Bed III times (van der Merwe, 2013). Beginning 1.15 Ma, the main 531 drainageways passed through EN to end $5 \mathrm{~km}$ north of the site (Kleindienst, 1973; Hay, 1976). 
532 These streams likely originated near Lemagrut and Sadiman volcanoes. The ${ }^{87} \mathrm{Sr} /{ }^{86} \mathrm{Sr}$ values of 533 their rocks encompass the values of the teeth analyzed here. The streams were likely a major water 534 source for flora and fauna and would have contributed to the area’s bioavailable strontium.

535 Volcanism appears not to have been responsible for the differences in bioavailable 536 strontium. The active volcanic centre in the NVH shifted gradually southwest to northeast, and $537{ }^{87} \mathrm{Sr} /{ }^{86} \mathrm{Sr}$ values of the volcanoes decrease moving northeast from about 0.706 to 0.704 (Manega, 538 1993; Mollel et al., 2011). Bed III tuffs were likely deposited by Embagai and Loolmalasin 539 (Manega, 1993; Mollel and Swisher, 2012; Greenwood, 2014). We found no data on Loolmalasin’s $540 \quad{ }^{87} \mathrm{Sr} /{ }^{86} \mathrm{Sr}$ values, but it is near Embagai and Olmoti which have lavas ranging from $\sim 0.7041$ to 5410.7050 (Mollel, 2007), close to those of Oldoinyo Lengai today.

\section{Conclusion}

While ${ }^{87} \mathrm{Sr} /{ }^{86} \mathrm{Sr}$ variation in this region is limited, trends exist which may be related to 545 environmental factors. It would be impossible to re-trace small-scale movements, but Copeland et 546 al. (2012) found much higher values in Manyara and Serengeti National Parks, so large-scale 547 dispersals over hundreds of kilometers will be observable. This isoscape should be expanded to 548 connect with areas sampled by Copeland et al. (2012) and to include the diverse volcanic rocks of 549 the NVH.

Preliminary archaeological ${ }^{87} \mathrm{Sr} /{ }^{86} \mathrm{Sr}$ results suggest that diagenesis can be reversed with 551 weak acetic acid, and that modern and ancient bioavailable strontium differ. Sequential sampling 552 of teeth and a multi-isotope approach $\left(\delta^{13} \mathrm{C}\right.$ and $\left.\delta^{18} \mathrm{O}\right)$ could refine interpretations of mobility by 553 accounting for vegetation and precipitation patterns (e.g. Bentley et al., 2008; Widga et al., 2010). 
554 Future studies should note how palaeoenvironments differ from modern ones when interpreting 555 isotopic data and consider how this may have impacted hominin and animal behaviour.

556

557 Acknowledgements

558 Our work was sponsored by the Canadian Social Sciences and Humanities Research 559 Council under its Partnership Grant Program no. 895-2016-1017. The Tanzania Commission for 560 Science and Technology authorized our work under permit no. 2018-112-NA-2018-36. The 561 Tanzanian Ministry of Natural Resources and Tourism, through its Antiquities Division, granted 562 permission to carry out our work [14/2017/2018], and the Ngorongoro Conservation Area to enter 563 its protected area [BE.504/620/01/53]. The Tanzanian export license for the materials came from 564 the Antiquities division [EA.150/297/01: 5/2018/2019] and the Tanzanian Executive Secretary 565 from the Mining Commission [00001258] who authorized exportation to the University of 566 Calgary. We thank the staff of the National Herbarium of Tanzania for providing plant 567 identifications, and Kerri Miller and Michael Wieser for their assistance and guidance at the 568 Isotope Science Laboratory in the Physics and Astronomy department at the University of Calgary 569 (Canada). 
571 Albert, R.M., Bamford, M.K., Stanistreet, I., Stollhofen, H., Rivera-Rondon, C., Rodriguez-Cintas, 572 A. 2015. Vegetation landscape at DK locality, Olduvai Gorge, Tanzania. Palaeogeogr. Palaeocl. 573 426, 34-45. doi: 10.1016/j.palaeo.2015.02.022

574

575

576

577

578

579

580

581

582

583

584

585

586

587

588

589

590

591

592

593

594

595

596

597

598

599

600

601

602

603

604

605

606

607

608

609

610

611

612

Anderson, G.D., Talbot, L.M. 1965. Soil factors affecting the distribution of the grassland types and their utilization by wild animals on the Serengeti Plains, Tanganyika. J. Ecol. 53 (1), 33-56. doi: $10.2307 / 2257564$

Andersson, P., Löfvendahl, R., Åberg, G. 1990. Major element chemistry, $\delta^{2} \mathrm{H}, \delta^{18} \mathrm{O}$ and ${ }^{87} \mathrm{Sr} /{ }^{86} \mathrm{Sr}$ in a snow profile across central Scandinavia. Atmos. Environ. A-Gen. 24 (10), 2601-2608. doi: 10.1016/0960-1686(90)90138-D

Ashley, G.M., Hay, R.L. 2002. Sedimentation patterns in a Plio-Pleistocene volcaniclastic riftplatform basin, Olduvai Gorge, Tanzania. In: Renaut, R.W., Ashley, G.M., editors. Sedimentation in continental rifts. SEPM Special Publication 37, 107-122.

Bakker, E.S., Pages, J.F., Arthur, R., Alcoverro, T. 2016. Assessing the role of large herbivores in the structuring and functioning of freshwater and marine angiosperm ecosystems. Ecography 39, 162-179. doi: 10.1111/ecog.01651

Balasse, M. 2003. Potential biases in sampling design and interpretation of intra-tooth isotope analysis. Int. J. Osteoarchaeol. 13, 3-10. doi: 10.1002/oa.656

Bamford, M.K. 2005. Early Pleistocene fossil wood from Olduvai Gorge, Tanzania. Quatern. Int. 129, 15-22. doi: 10.1016/j.quaint.2004.04.003

Bamford, M.K. 2012. Fossil sedges, macroplants, and roots from Olduvai Gorge, Tanzania. J. Hum. Evol. 63(2), 351-363. doi: 10.1016/j.jhevol.2011.07.001

Bamford, M.K., Albert, R.M., Cabanes, D. 2006. Plio-Pleistocene macroplant fossil remains and phytoliths from Lowermost Bed II in the eastern palaeolake margin of Olduvai Gorge, Tanzania. Quatern. Int. 148, 95-112. doi: 10.1016/j.quaint.2005.11.027

Bamford, M.K., Stanistreet, I.G., Stollhofen, H., Albert, R.M. 2008. Late Pliocene grassland from Olduvai Gorge, Tanzania. Palaeogeogr. Palaeocl. 257(3), 280-293. doi: 10.1016/j.palaeo.2007.09.003

Barboni, D., Ashley, G.M., Domínguez-Rodrigo, M., Bunn, H.T. 2010. Phytoliths infer locally dense and heterogeneous paleovegetation at FLK North and surrounding localities during upper Bed I time, Olduvai Gorge, Tanzania. Quaternary Res. 74(3), 344-354. doi: 10.1016/j.yqres.2010.09.005 
Beard, B.L., Johnson, C.M. 2000. Strontium isotope composition of skeletal material can determine the birth place and geographic mobility of humans and animals. J. Forensic Sci. 45 (5), 1049-1061. doi: 10.1520/JFS14829J.

Bell, K., Simonetti, A. 1996. Carbonatite magmatism and plume activity: Implications from the $\mathrm{Nd}, \mathrm{Pb}$ and $\mathrm{Sr}$ isotope systematics of Oldoinyo Lengai. J. Petrol. 37 (6), 1321-1339. doi: 10.1093/petrology/37.6.1321

Bentley, R.A. 2006. Strontium isotopes from the Earth to the archaeological skeleton: A review. J. Archaeol. Method Theory 13 (3), 135-187. doi: 10.1007/s10816-006-9009-X

Bentley, R.A., Price, T.D., Stephan, E.. 2004. Determining the 'local' ${ }^{87} \mathrm{Sr} /{ }^{86} \mathrm{Sr}$ range for archaeological skeletons: A case study from Neolithic Europe. J. Archaeol. Sci. 31, 365-375. doi: 10.1016/j.jas.2003.09.003

Bentley, R.A., Wahl, J., Price, T.D., Atkinson, T.C. 2008. Isotopic signatures and hereditary traits: Snapshot of a Neolithic community in Germany. Antiquity 82, 290-304. doi: 10.1017/S0003598X00096812

Blumenschine, R.J., Stanistreet, I.G., Njau, J.K., Bamford, M.K., Masao, F.T., Albert, R.M., Stollhofen, H., Andrews, P., Prassack, K.A., McHenry, L.J., Fernandez-Yalvo, Y., Camilli, E.L., Ebert, J.I. 2012. Environments and hominin activities across the FLK peninsula during Zinjanthropus times (1.84 Ma), Olduvai Gorge, Tanzania. J. Hum. Evol. 63 (2), 364-383. doi: 10.1016/j.jhevol.2011.10.001

Böhlke, J.K., Horan, M. 2000. Strontium isotope geochemistry of groundwaters and streams affected by agriculture, Locust Grove, MD. Appl. Geochem. 15 (5), 599-609. doi: 10.1016/S08832927(99)00075-X

Brennan, S.R., Torgersen, C.E., Hollenbeck, J.P., Fernandez, D.P., Jensen, C.K., Schindler, D.E. 2016. Dendritic network models: Improving isoscapes and quantifying influence of landscape and in-stream processes on strontium isotopes in rivers. Geophys. Res. Lett. 43 (10), 5043-5051. doi: 10.1002/2016GL068904.

Britton, K., Grimes, V., Dau, J., Richards, M.P. 2009. Reconstructing faunal migrations using intra-tooth sampling and strontium and oxygen isotope analyses: a case study of modern caribou (Rangifer tarandus granti). J. Archaeol. Sci. 36, 1163-1172. doi:10.1016/j.jas.2009.01.003

Britton, K., Grimes, V., Niven, L., Steele, T.E., McPherron, S., Soressi, M., Kelly, T.E., Jaubert, J., Hublin, J.J., Richards, M.P. 2011. Strontium isotope evidence for migration in late Pleistocene Rangifer: Implications for Neanderthal hunting strategies at the Middle Palaeolithic site of Jonzac, France. J. Hum. Evol. 61, 176-185. doi: 10.1016/j.jhevol.2011.03.004

Budd, P., Montgomery, J., Barreiro, B., Thomas, R.G. 2000. Differential diagenesis of strontium in archaeological human dental tissues. Appl. Geochem. 15, 687-694. doi: 10.1016/S08832927(99)00069-4 
Capo, R.C., Stewart, B.W., Chadwick, O.A. 1998. Strontium isotopes as tracers of ecosystem processes: Theory and methods. Geoderma 82:197-225. doi: 10.1016/S0016-7061(97)00102-X

Caverley, P.M., Downs, C.T. 2015. Movement and home range of Nile crocodiles in Ndumo Game Reserve, South Africa. Koedoe 51(1). doi: 10.4102/koedoe.v57i1.1234.

Cerling, T.E., Hay, R.L. 1986. An isotopic study of paleosol carbonates from Olduvai Gorge. Quaternary Res. 25, 63-78. doi: 10.1016/0033-5894(86)90044-X

Chorowicz, J. 2005. The East African rift system. J. Afr. Earth Sci. 43, 379-410. doi: 10.1016/j.jafrearsci.2005.07.019

Clow, D.W., Mast, M.A., Bullen, T.D., Turk, J.T. 1997. Strontium 87/strontium 86 as a tracer of mineral weathering reactions and calcium sources in an alpine/subalpine watershed, Loch Vale, Colorado. Water Resour. Res. 33 (6), 1335-1351. doi: 10.1029/97WR00856

Conlee, C.A., Buzon, M.R., Noriega Gutierrez, A., Simonetti, A., Creaser, R.A. 2009. Identifying foreigners versus locals in a burial population from Nasca, Peru: An investigation using strontium isotope analysis. J. Archaeol. Sci. 36 (12), 2755-2764. doi: 10.1016/j.jas.2009.08.016

Copeland, S.R., Cawthra, H.C., Fisher, E.C., Lee-Thorp, J.A., Cowling, R.M., le Roux, P.J., Hodgkins, J., Marean, C.W. 2016. Strontium isotope investigation of ungulate movement patterns on the Pleistocene Paleo-Agulhas Plain of the Greater Cape Floristic Region, South Africa. Quaternary Sci. Rev. 141, 65-84. doi: 10.1016/j.quascirev.2016.04.002

Copeland, S.R., Reed, D., Blumenschine, R.J., Njau, J., Sponheimer, M., Richards, M.P. 2012. Tracking ancient animal movements in northern Tanzania using strontium isotopes. Am. J. Phys. Anthropol. 147, 120-120.

Copeland, S.R., Sponheimer, M., de Ruiter, D.J., Lee-Thorp, J.A., Codron, D., le Roux, P.J., Grimes, V., Richards, M.P. 2011. Strontium isotope evidence for landscape use by early hominins. Nature 474, 76-78. doi:10.1038/nature10149

Dawson, J.B. 1992. Neogene tectonics and volcanicity in the North Tanzania sector of the Gregory Rift Valley: Contrasts with the Kenya sector. Tectonophysics 204, 81-92. doi: 10.1016/00401951(92)90271-7

Day, M.H., Molleson, T.I. 1976. The puzzle from JK2 - A femur and a tibial fragment (O.H. 34) from Olduvai Gorge, Tanzania. J. Hum. Evol. 5 (5), 455-465. doi: 10.1016/0047-2484(76)900865

De la Torre, I., McHenry, L., Njau, J., Pante, M. 2012. The origins of the Acheulean at Olduvai Gorge (Tanzania): A new paleoanthropological project in East Africa. Archaeology International 15, 89-98. doi: 10.5334/ai.1505 
Deino, A.L. 2012. ${ }^{40} \mathrm{Ar} /{ }^{39} \mathrm{Ar}$ dating of Bed I, Olduvai Gorge, Tanzania, and the chronology of early Pleistocene climate change. J. Hum. Evol. 63 (2), 251-273. doi: 10.1016/j.jhevol.2012.05.004

Diez-Martin, F., Sánchez Yustos, P., Uribelarrea, D., Baquedano, E., Mark, D.F., Mabulla, A., Fraile, C., Duque, J., Díaz, I., Pérez-González, A., Yravedra, J., Egeland, C.P., Organista, E., Domínguez-Rodrigo, M. 2015. The origin of the Acheulean: The 1.7 million-year-old site of FLK West, Olduvai Gorge (Tanzania). Sci. Rep-UK 5, 17839. doi: 10.1038/srep17839

Domínguez-Rodrigo, M. 1997. Meat-eating by early hominids at the FLK 22 Zinjanthropus site, Olduvai Gorge (Tanzania): An experimental approach using cut-mark data. J. Hum. Evol. 33 (6), 669-690. doi: 10.1006/jhev.1997.0161

Domínguez-Rodrigo, M., Cobo-Sánchez, L., Uribelarrea, D., Arriaza, M.C., Yravedra, J., Gidna, A., Organista, E., Sistiaga, A., Martín-Perea, D., Baquedano, E., Aramendi, J., Mabulla, A. 2017. Spatial simulation and modelling of the early Pleistocene site of DS (Bed I, Olduvai Gorge, Tanzania): A powerful tool for predicting potential archaeological information from unexcavated areas. Boreas 46(4), 805-815. doi: 10.1111/bor.12252

Domínguez-Rodrigo, M., Mabulla, A.Z.P., Bunn, H.T., Diez-Martin, F., Baquedano, E., Barboni, D., Barba, R., Domínguez-Solera, S., Sánchez, P., Ashley, G.M., Yravedra, J. 2010. Disentangling hominin and carnivore activities near a spring at FLK North (Olduvai Gorge, Tanzania). Quaternary Res. 74, 363-375. doi: 10.1016/j.yqres.2010.07.004

Domínguez-Rodrigo, M., Pickering, T.R., Almecija, S., Heaton, J.L., Baquedano, E., Mabulla, A., Uribelarrea, D. 2015. Earliest modern human-like handbone from a new $>1$.84-million-year-old site at Olduvai in Tanzania. Nat. Commun. 6, 7987. doi: 10.1038/ncomms8987

Domínguez-Rodrigo, M., Pickering, T.R., Baquedano, E., Mabulla, A., Mark, D.F., Musiba, C., Bunn, H.T., Uribelarrea, D., Smith, V., Diez-Martin, F., Pérez-González, A., Sánchez, P., Santonja, M., Barboni, D., Gidna, A., Ashley, G., Yravedra, J., Heaton, J.L., Arriaza, M.C. 2013. First partial skeleton of a 1.34-million-year-old Paranthropus boisei from Bed II, Olduvai Gorge, Tanzania. PLoS ONE 8 (12), e80347. doi: 10.1371/journal.pone.0080347

Ericson, J.E. 1985. Strontium isotope characterization in the study of prehistoric human ecology. J. Hum. Evol. 14, 503-514. doi: 10.1016/S0047-2484(85)80029-4

Estes, R.D. 2014. The gnu's world: Serengeti wildebeest ecology and life history. University of California Press, Berkeley.

Evans, J.A., Montgomery, J., Wildman, G. 2009. Isotope domain mapping of ${ }^{87} \mathrm{Sr} /{ }^{86} \mathrm{Sr}$ biosphere variation on the Isle of Skye, Scotland. J. Geol. Soc. London 166(4), 617-631. doi: 10.1144/0016-76492008-043

Evans, J.A., Montgomery, J., Wildman, G., Boulton, N. 2010. Spatial variations in biosphere ${ }^{87} \mathrm{Sr} /{ }^{86} \mathrm{Sr}$ in Britain. J. Geol. Soc. London 167, 1-4. doi: 10.1144/0016-76492009-090 
Faure, G. 1986. Principles of isotope geology, 2nd ed. John Wiley and Sons, New York.

Faure, G., Powell, J.L. 1972. Strontium isotope geology. Springer-Verlag, New York.

Fernández-Jalvo, Y., Andrews, P., Denys, C. 1999. Cut marks on small mammals at Olduvai Gorge Bed-I. J. Hum. Evol. 36, 587-589. doi: 10.1006/jhev.1999.0292

Flockhart, D.T.T., Kyser, T.K., Chipley, D., Miller, N.G., Norris, D.R. 2015. Experimental evidence shows no fractionation of strontium isotopes $\left({ }^{87} \mathrm{Sr} /{ }^{86} \mathrm{Sr}\right)$ among soil, plants, and herbivores: Implications for tracking wildlife and forensic science. Isot. Environ. Health. S. 5 (3), 372-381. doi: 10.1080/10256016.2015.1021345

Franzén, L.G. 1980. Transport, deposition and distribution of marine aerosols over southern Sweden during dry westerly storms. Ambio 19 (4), 180-188. https://www.jstor.org/stable/4313690

Frei, K.M., Frei, R. 2011. The geographic distribution of strontium isotopes in Danish surface waters - A base for provenance studies in archaeology, hydrology and agriculture. Appl. Geochem. 26, 326-340. doi:10.1016/j.apgeochem.2010.12.006

Frei, K.M., Price, T.D. 2012. Strontium isotopes and human mobility in prehistoric Denmark. Archaeol. Anthropol. Sci. 4, 103-114. doi: 10.1007/s12520-011-0087-7

Gosz, J.R., Brookins, D.G., Moore, D.I. 1983. Using strontium isotope ratios to estimate inputs to ecosystems. BioScience 33 (1), 23-30. doi: 10.2307/1309240

Graustein, W.C., Armstrong, R.L. 1983. The use of strontium-87/strontium-86 ratios to measure atmospheric transport into forested watersheds. Science 219 (4582), 289-292. doi: 10.1126/science.219.4582.289

Greenwood, S.M. 1994. Mineralogy and geochemistry of Pleistocene volcanics at Embagai caldera and Natron basin, Tanzania: Potential constraints on the stratigraphy of Olduvai Gorge (Master's Thesis). University of Wisconsin - Milwaukee, Ann Arbor.

Habermann, J.M., McHenry, L.J., Stollhofen, H., Tolosana-Delgado, R., Stanistreet, I.G., Deino, A.L. 2016. Discrimination, correlation, and provenance of Bed I tephrostratigraphic markers, Olduvai Gorge, Tanzania, based on multivariate analyses of phenocryst compositions. Sediment Geol 339, 115-133. doi: 10.1016/j.sedgeo.2016.03.026

Hartman, G., Richards, M. 2014. Mapping and defining sources of variability in bioavailable strontium isotope ratios in the Eastern Mediterranean. Geochim. Cosmochim. Acta 126, 250-264. doi: 10.1016/j.gca.2013.11.015

Hay, R.L. 1976. Geology of the Olduvai Gorge: A study of sedimentation in a semiarid basin. University of California Press, Berkeley.

Herlocker, D.J., Dirschl, H.J. 1972. Vegetation of the Ngorongoro Conservation Area, Tanzania. Ottawa, Canadian Wildlife Service Report Series 19. 
Hlusko, L.J., Reiner, W.B., Njau, J.K. 2015. A one-million-year-old hominid distal ulna from Olduvai Gorge, Tanzania. Am. J. Phys. Anthropol. 158 (1), 36-42. doi: 10.1002/ajpa.22765

Hodell, D.A., Quinn, R.L., Brenner, M., Kamenov, G.. 2004. Spatial variation of strontium isotopes $\left({ }^{87} \mathrm{Sr} /{ }^{86} \mathrm{Sr}\right)$ in the Maya region: a tool for tracking ancient human migration. J. Archaeol. Sci. 31, 585-601. doi: 10.1016/j.jas.2003.10.009

Holdo, R.M., Holt, R.D., Fryxell, J.M. 2009. Opposing rainfall and plant nutritional gradients best explain the wildebeest migration in the Serengeti. Am. Nat. 173 (4), 431-445. doi: 10.1086/597229

Hosono, T., Nakano, T., Igeta, A., Tayasu, I., Tanaka, T., Yachi, S. 2007. Impact of fertilizer on a small watershed of Lake Biwa: Use of sulfur and strontium isotopes in environmental diagnosis. Sci. Total Environ. 384 (1-3), 342-354. doi: 10.1016/j.scitotenv.2007.05.033

Jager, T. 1982: Soils of the Serengeti woodlands, Tanzania. Centre for Agricultural Publishing and Documentation, Wageningen.

Johanson, D.C., Masao, F.T., Eck, G.G., White, T.D., Walter, R.C., Kimbel, W.H., Asfaw, B., Manega, P., Ndessokia, P., Suwa, G. 1987. New partial skeleton of Homo habilis from Olduvai Gorge, Tanzania. Nature 327, 205-209. doi: 10.1038/327205a0

Kalt, A., Hegner, E., Satir, M. 1997. Nd, Sr, and Pb isotopic evidence for diverse lithospheric mantle sources of East African Rift carbonatites. Tectonophysics 278, 31-45. doi: 10.1016/S00401951(97)00093-0

Kennedy, A.S. 2014. Birds of the Serengeti and Ngorongoro Conservation Area. Princeton University Press, Princeton.

Kennedy, A.S., Kennedy, V. 2014. Animals of the Serengeti and Ngorongoro Conservation Area. Princeton University Press, Princeton.

Kindt, R., Van Breugel, P., Lillesø, J.B., Bingham, M., Demissew, S., Dudley, C., Friis, I., Gachathi, F., Kalema, J., Mbago, F., Minani, V., Moshi, H., Mulumba, J., Namaganda, M., Ndangalasi, H., Ruffo, C., Jamnadass, R., and Graudal, L. O. V. 2011. Potential Natural Vegetation of Eastern Africa (Ethiopia, Kenya, Malawi, Rwanda, Tanzania, Uganda and Zambia). Forest \& Landscape, University of Copenhagen.

Kleindienst, M.R. 1973. Excavations at site JK2, Olduvai Gorge, Tanzania, 1961-1962: The geological setting. Quaternaria 17, 145-208.

Knudson, K.J., Tung, T.A., Nystrom, K.C., Price, T.D., Fullagar, P.D. 2005. The origin of the Juch'uypampa Cave mummies: Strontium isotope analysis of archaeological human remains from Bolivia. J. Archaeol. Sci. 32, 903-913. doi: 10.1016/j.jas.2005.01.007 
Kootker, L.M., van Lanen, R.J., Kars, H., Davies, G.R. 2016. Strontium isoscapes in The Netherlands. Spatial variations in ${ }^{87} \mathrm{Sr} /{ }^{86} \mathrm{Sr}$ as a proxy for palaeomobility. J. Archaeol. Sci. 6, 1-13. doi: 10.1016/j.jasrep.2016.01.015

Leakey, L.S.B., Tobias, P.V., Napier, J.R. 1964. A new species of the genus Homo from Olduvai Gorge. Nature 202, 7-9. doi: 10.1038/202007a0

Leakey, M.D. 1971. Olduvai Gorge volume 3, excavations in Beds I and II, 1960-1963. Cambridge University Press, Cambridge.

Leakey, M.D. 1978. Olduvai Gorge 1911-75: A history of the investigations. Geol. Soc. London Spec. Publ. 6 (1), 151-155. doi: 0.1144/GSL.SP.1978.006.01.12

Leakey, M.D., Roe, D. 1994. Olduvai Gorge volume 5: Excavations in Beds III, IV and the Masek Beds, 1968-1971. Cambridge University Press, Cambridge.

Lee, D.E., Kissui, B.M., Kiwango, Y.A., Bond, M.L. 2016. Migratory herds of wildebeests and zebras indirectly affect calf survival of giraffes. Ecol. Evol. 6, 8402-8411. doi: 10.1002/ece3.2561

Lee-Thorp, J., Manning, L., Sponheimer, M. 1997. Problems and prospects for carbon isotope analysis of ery small samples of fossil tooth enamel. Bull. Soc. Geol. Fr. 168 (6), 767-773.

Lee-Thorp, J., Sponheimer, M. 2003. Three case studies used to reassess the reliability of fossil bone and enamel isotope signals for paleodietary studies. J. Anthropol. Archaeol. 22, 208-216. doi:10.1016/S0278-4165(03)00035-7

Manega, P.C. 1993. Geochronology, geochemistry and isotopic study of the Plio-Pleistocene hominid sites and the Ngorongoro Volcanic Highland in northern Tanzania (PhD dissertation). University of Colorado at Boulder, Ann Arbor.

Manya, S., Maboko, M.A.H., Nakamura, E. 2007. The geochemistry of high-Mg andesite and associated adakitic rocks in the Musoma-Mara Greenstone Belt, northern Tanzania: Possible evidence for Neoarchaean ridge subduction? Precambrian Res. 3-4, 241-259. doi: 10.1016/j.precamres.2007.07.002

Maurer, A.F., Galer, S.J.G., Knipper, C., Beierlein, L., Nunn, E.V., Peters, D., Tutken, T., Alt, K.W., Schone, B.R. 2012. Bioavailable ${ }^{87} \mathrm{Sr} /{ }^{86} \mathrm{Sr}$ in different environmental samples - Effects of anthropogenic contamination and implications for isoscapes in past migration studies. Sci. Total Environ. 433, 216-229. doi: 10.1016/j.scitotenv.2012.06.046

McHenry, H.M., Brown, C.C., McHenry, L.J. 2007. Fossil hominin ulnae and the forelimb of Paranthropus. Am. J. Phys. Anthropol. 134, 209-218. doi: 10.1002/ajpa.20656

McHenry, L.J., Mollel, G.F., Swisher III, C.C. 2008. Compositional and textural correlations between Olduvai Gorge Bed I tephra and volcanic sources in the Ngorongoro Volcanic Highlands, Tanzania. Quatern. Int. 178 (1), 306-319. doi: 10.1016/j.quaint.2007.01.004 
Mollel, G.F., Swisher III, C.C. 2012. The Ngorongoro Volcanic Highland and its relationship to volcanic deposits at Olduvai Gorge and East African Rift volcanism. J. Hum. Evol. 63, 274-283. doi: 10.1016/j.jhevol.2011.09.001

Mollel, G.F., Swisher III, C.C., Feigenson, M.D., Carr, M.J. 2008. Geochemical evolution of Ngorongoro Caldera, Northern Tanzania: Implications for crust-magma interaction. Earth and Planet. Sci. Lett. 271, 337-347. doi: 10.1016/j.epsl.2008.04.014

Mollel, G.F., Swisher III, C.C., Feigenson, M.D., Carr, M.J. 2011. Petrology, geochemistry, and age of Satiman, Lemagurut and Oldeani: Sources of the volcanic deposits of the Laetoli area. In: Harrison, T. (editor). Paleontology and geology of Laetoli: Human evolution in context, vol. 1. Springer, Dordrecht. p. 99-119.

Naidoo, R., Chase, M.J., Beytell, P., Du Preez, P. 2016. A newly discovered wildlife migration in Namibia and Botswana is the longest in Africa. Oryx 50(1), 138-146. doi:10.1017/S0030605314000222

Norton-Griffiths, M., Herlocker, D., Pennycuick, L. 1975. The patterns of rainfall in the Serengeti Ecosystem, Tanzania. E. Afr. Wildl. J. 13, 347-374. doi: 10.1111/j.1365-2028.1975.tb00144.x

Nyamai, C.M., Mathu, E.M., Wallbrecher, E., Opiyo-Akech, N. 2001. A reappraisal of the geology, structures, and tectonics of the Mozambique Belt in Kenya east of the rift system. Gondwana Res. 4 (4), 720. doi: 10.1016/S1342-937X(05)70517-7

Nystrom, K.C., Amato, L.A., Jankowitz, L.A. 2011. Strontium isotopic reconstruction of the composition of an urban free black population from the $19^{\text {th }}$ century United States. J. Archaeol. Sci. 38 (12), 3505-3517. doi: 10.1016/j.jas.2011.08.013

Organista, E., Domínguez-Rodrigo, M., Egeland, C.P., Uribelarrea, D., Mabulla, A., Baquedano, E. 2016. Did Homo erectus kill a Pelorovis herd at BK (Olduvai Gorge)? A taphonomic study of BK5. Archael. Anthropol. Sci. 8 (3), 601-624. doi: 10.1007/s12520-015-0241-8

Palmer, M.R., Edmond, J.M. 1989. The strontium isotope budget of the modern ocean. Earth and Planet. Sc. Lett. 92, 11-26. doi: 10.1016/0012-821X(89)90017-4

Pante, M.C. 2013. The larger mammal fossil assemblage from JK2, Bed III, Olduvai Gorge, Tanzania: Implications for the feeding behavior of Homo erectus. J. Hum. Evol. 64, 68-82. doi: 10.1016/j.jhevol.2012.10.004

Pearsall, W.H. 1957. Report on an ecological survey of the Serengeti National Park, Tanganyika: November and December 1956. The Fauna Preservation Society, London.

Perry, M.A., Jennings, C., Coleman, D.S. 2017. Strontium isotope evidence for long-distance immigration into the Byzantine port city of Aila, modern Aqaba, Jordan. Archaeol. Anthropol. Sci. 9(5), 943-964. doi: 10.1007/s12520-016-0314-3 
Poszwa, A., Ferry, B., Dambrine, E., Pollier, B., Wickman, T., Loubet, M., Bishop, K. 2004. Variations of bioavailable Sr concentration and ${ }^{87} \mathrm{Sr} /{ }^{86} \mathrm{Sr}$ ratio in boreal forest ecosystems: Role of biocycling, mineral weathering and depth of root uptake. Biogeochemistry 67, 1-20. doi: 10.1023/B:BIOG.0000015162.12857.3e

Rightmire, G.P. 1979. Cranial remains of Homo erectus from Beds II and IV, Olduvai Gorge, Tanzania. Am. J. Phys. Anthropol. 51 (1), 99-115. doi: 10.1002/ajpa.1330510113

Scoon, R.N. 2018. Geology of national parks of Central/Southern Kenya and Northern Tanzania: Geotourism of the Gregory Rift Valley, active volcanism and regional plateaus. Springer International Publishing, Cham.

Sikes, N.E., Ashley, G.M. 2007. Stable isotopes of pedogenic carbonates as indicators of paleoecology in the Plio-Pleistocene (upper Bed I) western margin of the Olduvai Basin, Tanzania. J. Hum. Evol. 53, 574-594. doi: 10.1016/j.jhevol.2006.12.008

Sillen, A. 1986. Biogenic and diagenetic Sr/Ca in Plio-Pleistocene fossils of the Omo Shungura formation. Paleobiology 12, 311-323. http://www.jstor.org/stable/2400437

Sillen, A., Sealy, J.C. 1995. Diagenesis of strontium in fossil bone: A reconsideration of Nelson et al. (1986). J. Archaeol. Sci. 22, 313-320. doi: 10.1006/jasc.1995.0033

Sillen, A., Hall. G., Armstrong, R. 1995. Strontium calcium ratios (Sr/Ca) and strontium isotopic ratios $\left({ }^{87} \mathrm{Sr} /{ }^{86} \mathrm{Sr}\right)$ of Australopithecus robustus and Homo sp. from Swartkrans. J. Hum. Evol. 28, 277-285. doi: 10.1006/jhev.1995.1020

Sillen, A., Hall, G., Richardson, S., Armstrong, R. $1998 .{ }^{87} \mathrm{Sr} /{ }^{86} \mathrm{Sr}$ ratios in modern and fossil foodwebs of the Sterkfontein Valley: Implications for early hominid habitat preference. Geochim. Cosmochim. Acta 62 (14), 2463-2473. doi: 10.1016/S0016-7037(98)00182-3

Slovak, N.M., Paytan, A., Wiegand, B.A. 2009. Reconstructing Middle Horizon mobility patterns on the coast of Peru through strontium isotope analysis. J. Archaeol. Sci. 36 (1), 157-165. doi: 10.1016/j.jas.2008.08.004

Stewart, B.W., Capo, R.C., Chadwick, O.A. 2001. Effects of rainfall on weathering rate, base cation provenance, and Sr isotope composition of Hawaiian soils. Geochim. Cosmochim. Acta 65 (7), 1087-1099. doi: 10.1016/S0016-7037(00)00614-1

Van der Merwe, N.J. 2013. Isotopic ecology of fossil fauna from Olduvai Gorge at ca 1.8 Ma, compared with modern fauna. S. Afr. J. Sci. 109(11/12), 64-77. doi: 10.1590/sajs.2013/20130105.

Wadleigh, M.A., Veizer, J., Brooks, C. 1985. Strontium and its isotopes in Canadian rivers: Fluxes and global implications. Geochim. Cosmochim. Acta 49, 1727-1736. doi: 10.1016/00167037(85)90143-7 
979 Whipkey, C.E., Capo, R.C., Chadwick, O.A., Stewart, B.W. 2000. The importance of sea spray to 980 the cation budget of a coastal Hawaiian soil: A strontium isotope approach. Chem. Geol. 168 (1981 2), 37-48. doi: 10.1016/S0009-2541(00)00187-X

982

983 Widga, C., Walker, J.D., Stockli, L.D. 2010. Middle Holocene bison diet and mobility in the 984 eastern Great Plains (USA) based on $\delta^{13} \mathrm{C}, \delta^{18} \mathrm{O}$, and ${ }^{87} \mathrm{Sr} /{ }^{86} \mathrm{Sr}$ analyses of tooth enamel carbonate. 985 Quaternary Res. 73 (3), 449-463. doi:10.1016/j.yqres.2009.12.001

986

987 Wright, L.E. 2012. Immigration to Tikal, Guatemala: Evidence from stable strontium and oxygen 988 isotopes. J. Anthropol. Archaeol. 31(3), 334-352. doi: 10.1016/j.jaa.2012.02.001 